\title{
Effects of histocompatibility and host immune responses on the tumorigenicity of pluripotent stem cells
}

\author{
Ralf Dressel
}

Received: 3 January 2011 / Accepted: 16 March 2011 /Published online: 4 April 2011

(C) The Author(s) 2011. This article is published with open access at Springerlink.com

\begin{abstract}
Pluripotent stem cells hold great promises for regenerative medicine. They might become useful as a universal source for a battery of new cell replacement therapies. Among the major concerns for the clinical application of stem cell-derived grafts are the risks of immune rejection and tumor formation. Pluripotency and tumorigenicity are closely linked features of pluripotent stem cells. However, the capacity to form teratomas or other tumors is not sufficiently described by inherited features of a stem cell line or a stem cell-derived graft. The tumorigenicity always depends on the inability of the recipient to reject the tumorigenic cells. This review summarizes recent data on the tumorigenicity of pluripotent stem cells in immunodeficient, syngeneic, allogeneic, and xenogeneic hosts. The effects of immunosuppressive treatment and cell differentiation are discussed. Different immune effector mechanisms appear to be involved in the rejection of undifferentiated and differentiated cell populations. Elements of the innate immune system, such as natural killer cells and the complement system, which are active also in syngeneic recipients, appear to preferentially reject undifferentiated cells. This effect could reduce the risk of tumor formation in immunocompetent recipients. Cell differentiation apparently increases susceptibility to rejection by the adaptive immune system in allogeneic hosts. The current data suggest that the immune system of the recipient has a major impact on the outcome of
\end{abstract}

This article is published as part of the special issue on Immunopathology of Pluripotent Stem Cell Transplantation [33:6].

R. Dressel $(\bowtie)$

Department of Cellular and Molecular Immunology,

University of Göttingen,

Humboldtallee 34,

37073 Göttingen, Germany

e-mail: rdresse@gwdg.de pluripotent stem cell transplantation, whether it is rejection, engraftment, or tumor development. This has to be considered when the results of experimental transplantation models are interpreted and even more when translation into clinics is planned.

Keywords Pluripotent stem cells · Transplantation . Tumorigenicity · Teratoma . Engraftment $\cdot$ Rejection . Cytotoxic T lymphocytes $\cdot$ NK cells

The relation of pluripotency and tumorigenicity in stem cells-a challenge for regenerative medicine

Pluripotent stem cells can in principle differentiate into all cell types of the human body. Therefore, they have the potential for being used as source of transplantable cells for many different tissues and may offer new possibilities to treat various human diseases [1]. However, the use of human embryonic stem cells (ESCs) is restricted due to severe ethical concerns. Fortunately, new pluripotent cell types derived from adult organisms have been described. The most spectacular breakthrough in this field was obtained by reprogramming of mouse and human somatic cells into induced pluripotent stem cells (iPSCs) using a defined set of transcription factors [2-5]. Notably, pluripotent cells can also be obtained without the need of genetic manipulation from the testis of neonatal [6] and adult mice [7]. The so-called multipotent adult germ-line stem cells (maGSCs) can be differentiated in vitro into various cell types, including cardiomyocytes [8] and neuronal cells $[9,10]$, and they form teratomas in vivo $[7,11]$. The generation of pluripotent cells from adult human testis has also been recently reported [12-14], but the properties of these human germ-line stem cells are currently debated [15]. 
A hallmark of all pluripotent stem cell types, which demonstrates their potential to differentiate in all tissue types, is their ability to form teratomas in suitable hosts. This already indicates the close relationship of pluripotency and tumorigenicity in pluripotent stem cells. Therefore, it is not surprising that the risk of tumor formation is among the major hurdles that must be overcome before implementation of pluripotent stem cells into clinical practice [16-20]. Teratoma formation in immunodeficient mice is a key assay to determine the pluripotency of stem cells [21, 22]. Teratomas are tumors that contain tissues of ectodermal, mesodermal, and endodermal origin and the teratoma assay is therefore a relatively easy tool to demonstrate the ability of stem cells to differentiate in tissues derived from all three embryonic germ layers. For human stem cells, this assay is currently the ultimate test of pluripotency [23]. The blastocyst chimerism or tetraploid embryo complementation followed by gestation, which is used in mouse stem cell research as even better proof of pluripotency [24, 25], is prohibited in humans for ethical reasons. Fully differentiated or mature teratomas are composed only of nonproliferating somatic tissue. Immature teratomas contain additionally proliferating fetal-like cells. Teratomas growing after injection of pluripotent stem cells into animal models are usually non-malignant immature or mature teratomas $[16,21,26]$. However, in some cases, invasive or even metastatic tumors were observed after transplantation of pluripotent stem cells or their derivatives so that malignant teratocarcinoma-like tumors might occasionally occur [27]. Teratocarcinomas are defined to contain, in addition to differentiated tissues and normal immature precursor cells, also malignant cells that are equivalent to embryonal carcinoma (EC) cells in humans [28]. Genetic alteration during cell culture might be one reason for a more malignant phenotype of some pluripotent stem cell lines. The generation of iPSCs from adult cells that have acquired somatic mutations before being reprogrammed and gain additional genetic and epigenetic alterations during the reprogramming process aggravates this problem [29-31]. However, mutations giving rise to a more malignant phenotype of pluripotent stem cells will not be discussed in this review.

Interestingly, mouse ESCs appear to have a higher risk to form teratocarcinomas in mice compared to human ESCs [16]. The reasons could include species-specific growth factors, which lack in xenogeneic hosts, but also a more efficient immune-mediated rejection of xenogeneic malignant cells. In this case, human ESCs or other pluripotent stem cell types could have a higher risk to form teratocarcinomas in human recipients than predicted by mouse experiments [16]. Since pluripotency and tumorigenicity of pluripotent stem cells are so closely related, it is not clear whether these phenomena can be uncoupled in any stem cell line [32]. Pluripotent cells are therefore unlikely to be used directly in regenerative medicine. More likely, pluripotent stem cell-derived progenitor cells or differentiated cells will be transplanted in future cell or tissue replacement therapies [32]. However, it is presently not clear, which degree of developmental plasticity is required for cellular grafts. Terminally differentiated cells are presumably safe with respect to tumorigenicity but they might have a limited therapeutic efficacy at least for potential indications that require integration into host tissues.

Despite efforts to remove tumorigenic cells from grafts by various means including prolonged differentiation [33], cell sorting or selection [34-37], introduction of suicide genes [38, 39], and killing of undifferentiated cells prior to transplantation [40-42], all grafts that are derived from pluripotent stem cells are in principle at risk of containing teratoma-forming cells [32]. It is not known how many or few contaminating pluripotent cells could be acceptable with respect to the safety of a therapeutic graft. Notably, as few as two mouse ESCs [43] or 245 human ESCs [44] were reported to be able to form teratomas in immunodeficient mice. Importantly, teratomas and teratocarcinomas are not the only tumors that can form out of stem cell-derived grafts [19]. Transplantation of grafts containing nonpluripotent lineage committed stem cells might lead to growth of tumors that are more restricted in their tissue composition [36, 45, 46]. However, even benign tumors or normal but ectopically grown tissues (so-called tissue overgrowth) arising after stem cell therapy could cause severe clinical problems and would be unacceptable for most potential therapeutic applications.

\section{Risks of fetal cell transplantations - a caveat also for stem cell-based transplantation therapies}

Two recent reports indicate that the risk of tumor formation even after fetal cell transplantation might be more serious than previously anticipated. A patient with Huntington's disease, who was transplanted into the striatum with human fetal neural tissues [47], developed graft-derived "mass lesions" indicating the potential for graft overgrowth following fetal neural cell transplantation [48]. These tumors were detected at autopsy when the patient died 121 months after the transplantation due to progression of the disease. The patient might have had clinical benefit from the transplants at earlier stages of the disease [48], and it has to be noticed that in other patients undergoing the same or similar procedures, no tumors were found at autopsy $[49,50]$. In a second more debated case, a child with ataxia telangiectasia was treated at the age of 9,10 , and 12 years with intracerebellar and intrathecal injections 
of human fetal neural cells and developed at the age of 13 years donor-derived brain tumors [51]. The transplantations were performed in a setting outside the scientific mainstream [52], and the clinical complications were treated and reported by a team not involved in the transplantation. Parts of the lesions were removed and identified to be glioneural tumors [51]. In both cases, the donor-origin of the tumors was proven by genetic means $[48,51]$. However, it is not clear whether the tumors indeed developed from neural stem cells that might have been present in the fetal cellular grafts. Therefore, the conclusions which can be drawn from these cases with respect to cellular transplantation therapies based on better defined stem cell populations or their purified derivatives, might be limited [53]. Nonetheless, both cases demonstrate that the risk of tumor formation has to be taken seriously even after fetal cell transplantations.

Notably, the immune system of both patients developing tumors after transplantation of allogeneic fetal cells was compromised. The patient with Huntington's disease received an immunosuppressive therapy with cyclosporine A (CsA) for 12 months after the surgery to avoid graft rejection [48]. More intriguingly, ataxia telangiectasia is associated with an immunodeficiency [51, 54] and the patient was treated for hypogammaglobulinemia since the age of 7 years [51]. Realization of the tumorigenic potential of the fetal grafts in these patients could in part be due to a failure of the recipient's immune system to control the growth of tumorigenic donor cells. Transplantation into an immune-privileged organ such as the brain, immunosuppressive treatment, or an inherited or acquired immunodeficiency might increase the risk of tumor formation derived from stem cell grafts.

\section{Tumorigenicity of stem cells-a failure of the recipient's immune system to reject tumor-forming cells}

Also, in experimental systems, the teratoma-forming capacity of a pluripotent stem cell line is not sufficiently described by inherited features of the stem cell line. The teratomas are always formed in a host. Close interactions between donor and host tissues were observed after grafting of human ESCs in immunodeficient mice. Mouse cells contributed mainly, but not solely, to the formation of vessels in the human teratomas [26, 55]. It is not well known which factors provided by the host support the formation of teratomas after injection of pluripotent cells. However, it is conceivable that growth factors, cytokines, and hormones produced by cells of the host influence or even promote teratoma formation [56].

In addition, the potential of a pluripotent stem cell line to form teratomas always depends on the failure of the recipient to reject the teratoma-forming cells. Therefore, the teratoma assay, which demonstrates the pluripotency of a stem cell line, is usually performed in immunodeficient animals to avoid rejection of the stem cells by the recipient's immune system. The therapeutic potential of stem cells and stem cell-derived grafts is currently examined in a large variety of animal models involving transplantations in syngeneic, allogeneic, or even xenogeneic settings with or without pharmacological immunosuppression. Furthermore, various immunodeficient animal models are used for that purpose. Results on the risk of tumor formation and on engraftment of stem cellderived transplants have always to be interpreted in view of the model that was used. Lack of teratoma formation in immunocompetent animal models receiving stem cell transplants may often reflect the ability of the host to reject tumorigenic cells rather than the absence of those cells from the grafts. In this case, transplantation of the same cells into another less immunocompetent or even immunocompromised recipient might have a much higher risk of tumor formation. On the other hand, tumor formation in an immunodeficient animal model could indicate a risk of tumor formation that is practically not present in an immunocompetent recipient. Before clinical application of new stem cell-based therapies, it will be necessary to examine the risk of tumor development as well as the chance of successful engraftment of stem cells or stem cell-derived grafts in various immunogenetic settings to realistically appraise both, risks and chances.

\section{Immune control of teratoma growth-results from immunodeficient animal models}

It is well known that mouse [57-66] and human ESCs [26, $41,42,44,55,67-74]$ give rise to teratomas when injected into immunodeficient hosts. The types of immunodeficient models used in these experiments include T, B, and natural killer (NK) cell-deficient RAG2 ${ }^{-/-} \mathrm{c} \mathrm{c}^{-/-}$[59], and SCID/ beige mice [26, 61, 68, 71, 73, 75], $\mathrm{T}$ and $\mathrm{B}$ cell-deficient SCID [41, 42, 44, 70, 72, 75], RAG1 ${ }^{-/}$[65], and NOD/ SCID mice [58, 69, 71, 76, 77], the latter having also an impairment of some innate immune functions. In addition, $\mathrm{T}$ cell-deficient nude mice $[43,55,60,62,64,66,76,78$, 79] and nude rats $[39,66]$ were used and found to allow for teratoma growth. These data indicate that the $\mathrm{T}$ cell deficiency in nude mice and rats is in principal sufficient to allow for the growth of allogeneic and even xenogeneic teratomas. However, it is still not clear which effects the types of immunodeficiency in these models have on tumor frequency, tumor growth kinetics, and the minimal number of cells that needs to be inoculated. 
Very few studies have systematically compared the tumorigenicity of stem cell lines in several immunodeficient models. Probably, the most comprehensive study was published by Drukker and colleagues for human ESCs [67]. They investigated teratoma growth after injection of $1 \times 10^{6}$ human ESCs under the kidney capsule of NOD/SCID (T and B cell-deficient), BALB-nude ( $\mathrm{T}$ cell-deficient), C57BL/6-Lyst ${ }^{\text {bg }}$ (NK cell-deficient), and $\mathrm{CBA} / \mathrm{CaHN}$ $\mathrm{Btk}^{\mathrm{xid}}$ (B cell-deficient) mice. They found that $\mathrm{T}$ cells rather than $\mathrm{B}$ or NK cells were important for the rejection of the human ESCs because teratomas were only observed in the T cell-deficient models, i.e., NOD/SCID and nude mice at least within 5 weeks after transplantation [67]. Swijnenburg and colleagues compared teratoma growth after intramuscular injection of $1 \times 10^{6}$ human ESCs into NOD/SCID, BALB-nude, $\mathrm{CD} 4^{-/-}$, and $\mathrm{CD} 8 \mathrm{a}^{-/-}$mice [77]. Teratomas were formed in NOD/SCID and nude mice. The transplanted cells were rejected both in $\mathrm{CD} 4^{-/}$and $\mathrm{CD} 8 \mathrm{a}^{-/}$ mice but with a faster kinetics in $\mathrm{CD} 8 \mathrm{a}^{-/-}$recipients suggesting CD4-postive helper $\mathrm{T}$ cells to be more important for the rejection of xenogeneic ESCs than CD8-positive cytotoxic T cells (CTLs) [77].

It was confirmed that $\mathrm{B}$ cells are not important for mouse ESC rejection when $\mathrm{B}$ cell-deficient $\mathrm{JH}^{-/-}$mice were used as recipients and did not develop teratomas [59]. In the same study, mouse ESCs, in contrast to in vitrodifferentiated cardiomyocytes, were shown to be highly susceptible to lysis mediated by the alternative antibodyindependent complement pathway. In $\mathrm{C}^{-/-}$mice lacking the $\mathrm{C} 3$ complement factor, the growth of teratomas from syngeneic ESCs was accelerated at higher cell numbers $\left(1 \times 10^{6}\right)$ compared to wild-type hosts and the complement system prevented tumor formation by smaller cell numbers $\left(1 \times 10^{5}\right)$ in wild-type mice but not in $\mathrm{C}^{-/-}$mice [59].

Effects of NK cells on rejection of ESCs have also been reported. Teratomas derived from human ESCs grew faster in $\mathrm{T}, \mathrm{B}$, and $\mathrm{NK}$ cell-deficient SCID/beige compared to $\mathrm{T}$ and B cell-deficient NOD/SCID mice, suggesting an effect of mouse NK cells on human teratoma growth kinetics [71]. This was further confirmed by NK cell depletion experiments in NOD/SCID mice using anti-asialo GM-1 antibodies [71]. We have further investigated the role of mouse NK cells in rejection of mouse pluripotent stem cells by comparing teratoma growth in SCID and SCID/beige mice. The teratoma frequency was $93 \%$ in SCID/beige $(n=14)$ and $100 \%$ in SCID mice $(n=16)$ (Table 1) within 100 days after subcutaneous injection of $1 \times 10^{6}$ mouse MPI-II ESCs [61]. Notably, the tumor growth was accelerated in NK celldeficient SCID/beige compared to SCID mice (Fig. 1). In further experiments, the growth of an ESC, an iPSC, and a maGSC line was analyzed [75]. The overall teratoma frequency was $94 \%$ both in SCID and in SCID/beige mice $(n=18$; six for each stem cell line). Activation of NK cells in SCID mice by the Toll-like receptor 3 agonist poly(I:C) reduced the tumor frequency to $50 \%$ and decelerated teratoma growth [75]. This effect of poly(I:C) injection was not observed in SCID/beige mice, suggesting that it was indeed mediated by the activation of NK cells. Depletion of NK cells in SCID mice by anti-asialo GM1 antibodies prior to stem cell injection was also able to abrogate the poly(I:C) effect, further confirming the role of NK cells in rejection of pluripotent stem cells [75]. Thus, the elements of the innate immune system such as NK cells or complement system that are intact in many immunodeficient mouse models can contribute to the rejection of pluripotent stem cells.

The teratoma growth after injection of pluripotent stem cells in immunodeficient animals has been shown to depend on further factors, such as injected cell numbers [43, 44, 66, $72]$ and the site of engraftment [43, 44, 57, 69, 72, 73, 78]. The engraftment sites, including subcutaneous space, muscle, kidney capsule, testis, liver, spleen, and knee joint might vary with respect to the presence of teratomasupporting factors, such as nutrients or more specifically growth factors. However, they might also vary in accessibility for components of the immune system that are still present in the respective immunodeficient model and contribute to the rejection of the graft. It has been suggested, e.g., that the immune-privileged or tolerancepromoting environment within the liver may create more favorable growth conditions for human ESCs grafted into the liver of nude mice compared to those injected subcutaneously [78]. Similarly, teratomas developed more readily in SCID/beige mice after injection of human ESCs in the testis compared to the heart [73]. Co-injection of nonstem cells, such as fibroblasts $[43,66]$, or embedding of stem cells in Matrigel [43, 44, 66, 69] can also ameliorate the efficiency of teratoma formation. It can not be excluded that these factors modulate the immune response against the stem cells. Moreover, human ESCs were reported to form typical mature teratomas when injected into SCID mice but large tumors with undifferentiated OCT-4 positive cell masses when injected into human fetal grafts implanted into SCID mice [70]. Thus, human ESCs might grow more aggressively in a syngeneic microenvironment due to species-specific growth factors that are provided by the human fetal grafts [70]. Alternatively, aggressive tumorigenic cells might be less controllable by the innate immune system of the host, e.g., mouse NK cells, in a xenogeneic human microenvironment. The pluripotent stem cell type might also affect the teratoma growth characteristics. It has recently been reported that human iPSC lines form teratomas more efficiently and faster than human ESC lines in NOD/SCID IL2R $\gamma^{-/-}$hosts [74].

In conclusion, the results obtained in immunodeficient mouse models suggest that $\mathrm{T}$ cells are required to suppress 
Table 1 Frequency of teratoma formation after injection of ESCs or in vitro-differentiated cells in various hosts

\begin{tabular}{llll}
\hline Host & CsA & ESC & Differentiated cells (day 14) \\
\hline Syngeneic $\left(129 \mathrm{~Sv}, \mathrm{H} 2^{\mathrm{b}}\right)$ & - & $96 \%(25 / 26)$ & $95 \%(21 / 22)$ \\
Allogeneic $\left(\mathrm{C} 57 \mathrm{BL} / 6, \mathrm{H} 2^{\mathrm{b}}\right)$ & - & $0 \%(0 / 19)$ & $0 \%(0 / 25)$ \\
Allogeneic $\left(\mathrm{C} 3 \mathrm{H}, \mathrm{H} 2^{\mathrm{k}}\right)$ & - & $0 \%(0 / 13)$ & $0 \%(0 / 21)$ \\
Xenogeneic $\left(\mathrm{LOU} / \mathrm{c}, \mathrm{RT} 1^{\mathrm{u}}\right)$ & - & $0 \%(0 / 12)$ & $0 \%(0 / 17)$ \\
Allogeneic SCID/beige $\left(\mathrm{C} \cdot \mathrm{B}-17, \mathrm{H}^{\mathrm{d}}\right)$ & - & $93 \%(13 / 14)$ & $94 \%(17 / 18)$ \\
Allogeneic SCID $\left(\mathrm{C} \cdot \mathrm{B}-17, \mathrm{H}^{\mathrm{d}}\right)$ & - & $100 \%(15 / 15)$ & Not tested \\
Syngeneic $\left(129 \mathrm{~Sv}, \mathrm{H} 2^{\mathrm{b}}\right)$ & + & $94 \%(15 / 16)$ & $83 \%(10 / 12)$ \\
Allogeneic $\left(\mathrm{C} 57 \mathrm{BL} / 6, \mathrm{H} 2^{\mathrm{b}}\right)$ & + & $0 \%(0 / 12)$ & $8 \%(1 / 13)$ \\
Allogeneic $\left(\mathrm{C} 3 \mathrm{H}, \mathrm{H} 2^{\mathrm{k}}\right)$ & + & $7 \%(1 / 15)$ & $9 \%(1 / 11)$ \\
Xenogeneic $\left(\mathrm{LOU} / \mathrm{c}, \mathrm{RT} 1^{\mathrm{u}}\right)$ & + & $0 \%(0 / 25)$ & $61 \%(11 / 18)$ \\
\hline
\end{tabular}

MPI-II ESCs and cells differentiated in vitro for 14 days on PA6 feeder cells ( $>95 \%$ neuronal cells) were injected subcutaneously into the flank of syngeneic or allogeneic mice or xenogeneic rats $\left(1 \times 10^{6}\right.$ cells/animal). Some recipients received an immunosuppressive treatment with CsA $(10 \mathrm{mg} / \mathrm{kg} / \mathrm{day})$. The percentage and number of animals in which tumors were found during autopsy or in which tumors were palpable (at least during three consecutive observations) at the side of injection before day 100 after injection is indicated. The table is modified from [61]

CsA cyclosprin, ESC embryonic stem cell

teratoma growth after injection of allogeneic or xenogeneic pluripotent stem cells. Presence of functional NK cells appears regularly not to be sufficient to prevent teratomas after injection of high numbers of pluripotent stem cells. However, mouse NK cells can contribute to the rejection of smaller numbers of mouse and human stem cells and at least retard tumor growth, especially if NK cells become activated. Clearly, more studies are needed to better dissect the contribution of defined elements of the immune system to the rejection of pluripotent stem cells.

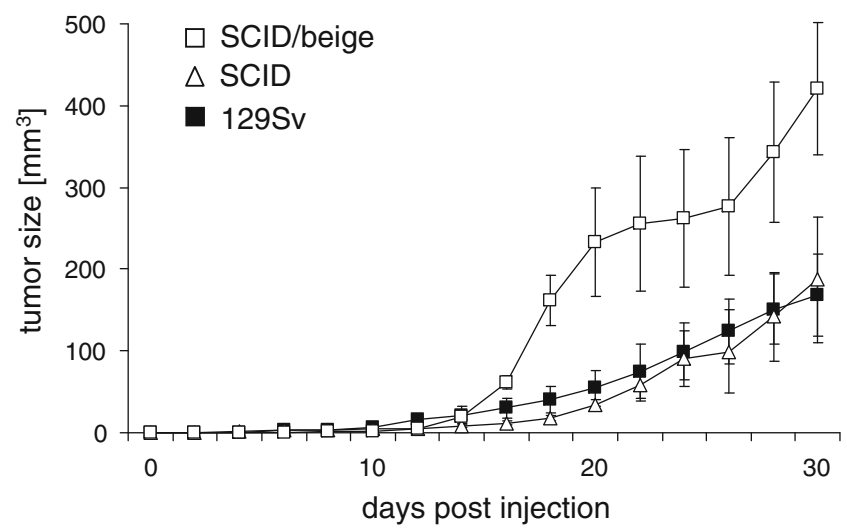

Fig. 1 Teratoma growth after injection of MPI-II ESCs is accelerated in SCID/beige compared to SCID and syngeneic $129 \mathrm{~Sv}$ mice. The $1 \times 10^{6}$ MPI-II ESCs were injected subcutaneously at day 0 into syngeneic $129 \mathrm{~Sv}$ mice $(n=26), \mathrm{T}$ and B cell-deficient SCID $(n=14)$ and T, B, and NK cell-deficient SCID/beige mice $(n=15)$. The tumor size was recorded every second day using linear calipers. A summary of the growth (mean \pm standard error of the mean) until day 30 is shown, newly evaluating previously published data [61]. The comparison of tumor size in SCID and SCID/beige or 129Sv mice, respectively, indicates a significant difference at days $18,20,22,28$, and $30(P<0.05$, unpaired $t$ test $)$

\section{Immune control of teratoma growth-results from syngeneic transplantations}

The injection of mouse ESCs into syngeneic hosts can lead to teratomas [36, 43, 60, 61, 80-82]. However, only few studies compared teratoma growth in immunodeficient and immunocompetent syngeneic hosts [43, 61]. Thus, the available information on the effects of a syngeneic immune system on transplanted pluripotent stem cells is very limited.

We compared the teratoma growth characteristics of MPI-II mouse ESCs in allogeneic immunodeficient and in immunocompetent syngeneic $129 \mathrm{~Sv}$ mice after subcutaneous injection of $1 \times 10^{6}$ cells (Table 1) [61]. Although the tumor frequency was similar $(96 \%$ in syngeneic, $93 \%$ in SCID/beige, and $100 \%$ in SCID hosts), the tumor growth characteristics were different. In SCID/beige mice, tumors grew more rapidly than in syngeneic and SCID hosts (Fig. 1). The similar growth kinetics in SCID and 129Sv mice suggests that the adaptive immune system is less important for the decelerated growth of teratomas in syngeneic compared to SCID/beige mice. Instead, NK cells might cause this transient delay of tumor progression. Interestingly, allogeneic (SCID) and syngeneic (129Sv) NK cells appear to have similar effects. The teratomas in syngeneic mice were infiltrated with $\mathrm{T}$ and $\mathrm{B}$ cells as well as macrophages, but these cells were obviously not able to reject the teratomas.

Lawrenz and colleagues compared the teratoma growth of J1 ESCs in immunodeficient BALB/c-nude and syngeneic $129 \mathrm{~Sv}$ mice [43]. They embedded ESCs in Matrigel before subcutaneous injection and found that tumor growth was delayed in syngeneic mice compared to immunodeficient hosts when 2,000 ESCs were injected. In addition, 
smaller numbers of ESCs were rejected in syngeneic recipients, whereas two ESCs were sufficient to form teratomas in more than $50 \%$ of the immunodeficient recipients [43].

Some studies determined the cell number required to form teratomas in syngeneic hosts. It was reported that $5 \times 10^{4}$ or less ESCs did not form teratomas after myocardial transplantation into syngeneic recipients, whereas $1 \times 10^{5}$ cells formed teratomas in $50 \%, 2.5 \times 10^{5}$ in $80 \%$, and $5 \times 10^{5}$ in $100 \%$ of the mice [60]. In our experiments aiming to define a tumorigenic dosis of MPI-II ESCs in syngeneic hosts, $2 \times 10^{6}$ and $1 \times 10^{6}$ MPI-II ESCs formed teratomas in six out of six syngeneic recipients after subcutaneous injection, whereas $5 \times 10^{5}$ cells resulted in teratomas in two out of six and $1 \times 10^{5}$ in one out of six hosts [61].

Thus, in a syngeneic setting, the immune system appears to be able to reject smaller numbers of pluripotent stem cells or to decelerate teratoma growth after injection of higher numbers of cells. Notably, it is not clear how regularly pluripotent stem cells form teratomas after syngeneic transplantation since negative results are unlikely to be reported. We observed that some pluripotent stem cell lines, which had readily formed teratomas in immunodeficient hosts, failed to form teratomas after injection into the syngeneic recipients (own unpublished observation). However, it is difficult to exclude the occurrence of genetic alterations between stem cell generation and transplantation experiments. Mutations might generate minor histocompatibility antigens that potentially could contribute to the rejection of the stem cell lines in formally syngeneic hosts.

In conclusion, mouse ESCs can apparently form teratomas in syngeneic recipients, but the innate immune system might be able to reject smaller numbers of pluripotent stem cells or to delay teratoma growth. Only few studies have been performed to determine the conditions required for teratomas in syngeneic recipients, such as minimal cell numbers or favorable injection sites. It is unclear whether newer pluripotent stem cell types, including iPSCs and maGSCs, which could potentially be used in autologous cell transplantation procedures, also form teratomas in syngeneic recipients. Although this can be expected, experimental studies are lacking that would allow to realistically extrapolate the risk of tumorigenicity associated with autologous pluripotent stem cell transplantations. In view of the extensively discussed perspectives of these cells for personalized medicine [83-87], this is somewhat surprising.

\section{Immune control of teratoma growth-results from allogeneic transplantations}

Some studies have compared syngeneic and allogeneic transplantations of mouse pluripotent stem cell lines [36,
$60,61,81,88-90]$ or analyzed allogeneic transplantations only $[8,58,91-94]$. The reported results are remarkably variable. Obviously, histocompatibility antigens can but must not suppress teratoma growth after injection of pluripotent stem cells into allogeneic hosts.

The introduction of genetic markers into ESC lines, which result in the expression of a single antigen, such as green fluorescent protein (GFP), usually does not prevent tumor growth in otherwise syngeneic recipients [60, 88]. However, minor histocompatibility antigens can be sufficient to prevent teratoma growth when ESCs are injected into hosts that share the major histocompatibility (MHC) locus but have different genetic backgrounds [60, 61, 65]. The mouse ESC line MPI-II, e.g., which formed teratomas in syngeneic $129 \mathrm{~Sv}$ mice $\left(\mathrm{H} 2^{\mathrm{b}}\right)$ after subcutaneous injection, failed to do so in $\mathrm{C} 57 \mathrm{BL} / 6$ mice that share the $\mathrm{H} 2^{\mathrm{b}}$ major histocompatibility antigens with $129 \mathrm{~Sv}$ mice but have a different genetic background (Table 1) [61]. In these experiments, the injection of male MPI-II cells into female 129Sv recipients had not prevented teratomas [61], indicating that $\mathrm{H}-\mathrm{Y}$ minor histocompatibility antigens encoded by the $\mathrm{Y}$ chromosome [95] are not sufficient to suppress teratomas in this experimental setting. In contrast, teratoma growth was accelerated in male compared to female hosts, suggesting an effect of male hormones on teratoma growth. These ESCs formed also no teratomas in minor and major histoincompatible $\mathrm{C} 3 \mathrm{H} / \mathrm{HeN}$ mice $\left(\mathrm{H} 2^{\mathrm{k}}\right)$ (Table 1) [61]. Thus, the degree of histocompatibility appears to be one important factor that determines the outcome of an allogeneic transplantation. This was also shown in a study comparing semiallogeneic and fully allogeneic transplantations [93]. In the semiallogeneic setting, in which $5 \times 10^{6}$ BALB/c x 129Sv-derived ESCs $\left(\mathrm{H}_{2}^{\mathrm{d}}\right.$ and $\left.\mathrm{H}^{\mathrm{b}}{ }^{\mathrm{b}}\right)$ were injected subcutaneously into BALB/c recipients $\left(\mathrm{H} 2^{\mathrm{d}}\right)$, teratomas grew in $100 \%$ of the hosts $(n=10)$ within 21 days. In the fully allogeneic combination, $1 \times 10^{6} \mathrm{C} 57 \mathrm{BL} / 6$ derived ESCs $\left(\mathrm{H}^{\mathrm{b}}{ }^{\mathrm{b}}\right)$ cells were rejected by BALB/c mice, but $5 \times 10^{6}$ cells formed teratomas in $30 \%$ and $20 \times 10^{6}$ cells even in $90 \%$ of the recipients [93]. Others observed teratomas after injection of $1 \times 10^{6}$ undifferentiated ESCs into infarcted hearts in 13 out of 13 syngeneic and two out of three allogeneic recipients [36].

The rejection of allogeneic mouse ESCs has been analyzed in more detail. Kofidis and colleagues injected $2.5 \times 10^{6}$ GFP-labeled 129Sv-derived D3 ESCs $\left(\mathrm{H}^{\mathrm{b}}{ }^{\mathrm{b}}\right)$ into ischemic hearts of immunodeficient SCID, syngeneic 129Sv $\left(\mathrm{H}_{2}{ }^{\mathrm{b}}\right)$, or allogeneic BALB/c $\left(\mathrm{H} 2^{\mathrm{d}}\right)$ recipients [90]. They followed the grafts up to 4 weeks after transplantation and found that only a small fraction of grafted cells developed into cells with a myofibrillar phenotype. The majority of the graft-derived cells were fibrocytes, chondrocytes, adenocytes, and endothelial cells. At 4 weeks, cellular dysplasia was described, but the grafts were not 
identified as teratomas. Notably, in the allogeneic situation, a vigorous graft rejection was observed at 4 weeks with an infiltration of grafts with $\mathrm{CD}^{+} \mathrm{T}$ cells, $\mathrm{CD} 11 \mathrm{c}^{+}$dendritic cells, circulation of donor-specific antibodies, and interferon (IFN)- $\gamma$ producing ESC-reactive T cells [90]. In a subsequent study, a higher number $\left(1 \times 10^{6}\right)$ of D3 ESCs $\left(\mathrm{H}_{2}{ }^{\mathrm{b}}\right)$ was injected into the ischemic hearts of syngeneic $129 \mathrm{~Sv}\left(\mathrm{H} 2^{\mathrm{b}}\right)$ and allogeneic BALB/c $\left(\mathrm{H} 2^{\mathrm{d}}\right)$ recipients [81]. After 1 and 2 weeks, the grafts were found in both recipients without signs of differentiation, indicating survival of largely undifferentiated ESCs. At 4 weeks, teratomas had formed in both types of recipients, and at 8 weeks they had been rejected in the allogeneic group in contrast to syngeneic hosts. Allogeneic ESCs elicited a progressive graft infiltration with various types of immune cells, including granulocytes, macrophages, dendritic cells, and $\mathrm{CD}^{+}$and $\mathrm{CD}^{+} \mathrm{T}$ cells. The time course of graft rejection suggested that the immunogenicity of ESC transplants increases with differentiation in vivo. These results were confirmed by an in vivo imaging study [88]. An intramuscular injection of $1 \times 10^{6}$ D3 ESCs into syngeneic $129 \mathrm{~Sv}$ mice resulted in teratomas, whereas grafts in allogeneic BALB/c mice were infiltrated by $\mathrm{CD}^{+}$and $\mathrm{CD}^{+} \mathrm{T}$ cells and rejected within 28 days in all recipients, unless higher numbers of ESCs were injected. Transplantation of $10 \times 10^{6}$ cells prolonged the survival of the allografts in some recipients. Interestingly, MHC class I and class II molecules were found to be strongly upregulated on teratoma cells compared to ESCs. Notably, the rejection of the 129Sv-derived D3 ESCs was accelerated in $\mathrm{BALB} / \mathrm{c}$ mice that were presensitized either with the D3 ESCs or splenocytes of $129 \mathrm{~Sv}$ mice [88] confirming the function of the adaptive immune system in the rejection of allogeneic teratomas.

Similar findings were reported in a further study [60]. In these experiments, $5 \times 10^{5}$ C57BL/6-derived ESCs $\left(\mathrm{H}_{2}{ }^{\mathrm{b}}\right)$ were injected into the myocardium of syngeneic mice and found to form teratomas. In allogeneic BALB/c recipients $\left(\mathrm{H}_{2}^{\mathrm{d}}\right)$, the grafts had proliferated after 1 week. At 2 weeks, first signs of epithelial differentiation became apparent, and at 3 weeks teratomas had formed, which were rejected 5 weeks after transplantation in $90 \%$ of the mice. The inflammatory response was compared after syngeneic and allogeneic transplantations by scoring the number of infiltrating $\mathrm{CD} 45^{+}$lymphocytes and found to be increased markedly at 3 weeks after inoculation of allogeneic compared to syngeneic stem cells. To test whether the rejection of allogeneic ESCs was strain or stem cell line dependent, a second model was evaluated. In this experimental series, $5 \times 10^{5}$ CGR8 ESCs from 129/Ola mice $\left(\mathrm{H} 2^{\mathrm{b}}\right.$ ) failed to form tumors in $\mathrm{C} 57 \mathrm{BL} / 6$ recipients $\left(\mathrm{H}^{\mathrm{b}}{ }^{\mathrm{b}}\right)$ after myocardial transplantations [60]. Notably, in this model of only minor histoincompatibility between transplants and hosts, the grafts could even not be detected in the myocardium of the recipients.

The immunological mechanisms involved in the rejection of allogeneic ESCs were further elucidated by $\mathrm{Wu}$ and colleagues [89]. They injected $1 \times 10^{6}$ cells under the kidney capsule of immunocompetent mice and found that fully allogeneic in contrast to syngeneic ESCs were infiltrated by macrophages, $\mathrm{CD}^{+}$, and $\mathrm{CD} 8^{+} \mathrm{T}$ cells and rejected within a few days [89]. However, when ESCs were transfected with an $\mathrm{H} 2 \mathrm{~K}^{\mathrm{b}}$ expression construct and transplanted in immunodeficient $\mathrm{RAG}^{-/-}$mice that were adoptively reconstituted with $\mathrm{T}$ cell receptor (TCR)-transgenic BM3 $\mathrm{T}$ cells recognizing the $\mathrm{MHC}$ class I molecule $\mathrm{H} 2 \mathrm{~K}^{\mathrm{b}}$ via the direct pathway of allorecognition, it turned out that the ESCs or their in vivo differentiation products were not able to activate a proliferative response of the BM3 $\mathrm{T}$ cells. The BM3 CTLs failed to infiltrate and reject the allografts. This failure was caused by a lack of professional donor antigenpresenting cells (APCs) in the graft. Co-transplantation of mature $\mathrm{H} 2 \mathrm{~K}^{\mathrm{b}}$-positive dendritic cells initiated an immune response of the BM3 CTLs against the allografts. When the recipients of ESCs were reconstituted with in vitro fully activated BM3 CTLs by adoptive transfer, the grafts were readily destroyed within 10 days. Thus, ESC-derived grafts can be rejected by alloreactive CTLs, if a CTL response becomes activated.

Not only a lack of donor-derived APCs might impair alloresponses against ESCs, stem cells might also actively suppress immune reactions. Yachimovich-Cohen and colleagues transplanted a high dose of $15 \times 10^{6} \mathrm{C} 57 \mathrm{BL} / 6$-derived ESCs $\left(\mathrm{H} 2^{\mathrm{b}}\right)$ subcutaneously into BALB/c recipients $\left(\mathrm{H}^{\mathrm{d}}\right)$ [91]. They found teratomas in 39\% (7 of 18) of the mice within 2 to 4 weeks. The teratomas were infiltrated by $\mathrm{T}$ cells but the $\mathrm{CD} 3 \zeta$-chain expression levels of these infiltrating $\mathrm{T}$ cells were significantly reduced compared with splenic $T$ cells from the same mice. This was attributed to the activity of the immunosuppressive enzyme arginase I in the stem cells. Arginase I degrades L-arginine and it has been shown that a low concentration of L-arginine in the microenvironment leads to local $\mathrm{T}$ cell unresponsiveness [96].

A very high incidence of teratoma formation after allogeneic transplantation of mouse ESCs was reported in a study by Magliocca and colleagues [58]. In an attempt to induce tolerance for subsequent transplantation of neonatal cardiac allografts $\left(\mathrm{H} 2^{\mathrm{b}}\right), \mathrm{BALB} / \mathrm{c}$ mice $\left(\mathrm{H} 2^{\mathrm{d}}\right)$ received an intraportal injection of $1 \times 10^{6}$ allogeneic ESCs $\left(\mathrm{H} 2^{\mathrm{b}}\right)$ [58]. While tolerance to the cardiac allografts was not achieved, $90 \%$ of the mice developed intrahepatic teratomas. One could speculate that the hepatic environment favors tolerance against the ESCs and therefore tumor formation. However, the authors reported teratomas also after intravenous or intramuscular injection of the allogeneic ESCs but gave no details on these experiments [58]. A high risk of 
teratomas was observed after transplantation of cynomolgus monkey ESCs into the fetal liver of allogeneic recipients [97-99]. In one of these studies, all transplanted animals developed teratomas although the cell line formed tumors only in three out of ten NOD/SCID mice [99].

A very low risk of teratomas in allogeneic recipients was found by Bonde and colleagues. Less than $2 \%$ of mice transplanted intravenously with $1 \times 10^{6}$ or $2 \times 10^{6}$ allogeneic ESCs developed teratomas but most showed engraftment leading to multi-lineage mixed chimerism of the hematopoietic system of the recipients [94]. Further studies have reported engraftment of allogeneic cells after transplantation of undifferentiated ESCs in immunocompetent mouse models for cardiac repair without tumor formation. Singla and colleagues transplanted $3 \times 10^{4}$ cells of two different 129-derived ESC lines $\left(\mathrm{H} 2^{\mathrm{b}}\right)$ into the infarcted myocardium of C57BL/6 mice $\left(\mathrm{H}_{2}{ }^{\mathrm{b}}\right)$ and found 2 weeks after grafting differentiation of the transplanted ESCs into cardiac cell types and improved cardiac function [92, 100]. It has been debated $[36,60]$ whether the methods to show engraftment in these studies were reliable since they based mainly on GFP or $\beta$-galactosidase expression in stem cells and their derivatives. Autofluorescence can mimic GFP expression and cell fusion events might occur that lead to expression of marker genes in hybrid cells. Functional improvement in these models of myocardial infarction could have been caused by mechanisms that do not depend on transplant survival. Thus, either these studies do not reliably indicate a survival of transplanted cells or they suggest that stem cells can escape from rejection by differentiation into other cell types. However, it has also to be noticed that the injected cell numbers in these studies were low and the observation time of 2 weeks is likely too short to observe teratomas.

In conclusion, it is well conceivable that the degree of histocompatibility as well as the circumstances (cell number, injection site, disease model, etc.) strongly influence the outcome of the injection of pluripotent stem cells across histocompatibility barriers. However, the tremendous variability of tumor risk observed after allogeneic stem cell transplantations warrants further studies to address this question more systematically.

\section{Immune control of teratoma growth-results from xenogeneic transplantations}

Transplantation of mouse and human ESCs into immunocompetent xenogeneic murine hosts usually does not lead to teratomas $[61,67,73,77]$ suggesting the rejection of xenogeneic stem cells or their derivatives formed in vivo by the recipient's immune system. However, some studies have reported engraftment of xenogeneic cells after transplantation of undifferentiated mouse ESCs in immu- nocompetent rat models for cardiac repair but there was no tumor formation [101-103]. Even repeated intravenous injections of as much as $1 \times 10^{7}$ mouse ESCs did not result in teratomas in Wistar rats with myocardial infarction but instead in myocardial homing of ESC-derived cells and functional improvements [104]. As mentioned before, it not clear whether methods to show engraftment based on expression of markers, such as GFP, are reliable. The short-term functional improvements observed in some studies after transplantation of xenogeneic ESCs could have been caused by paracrine effects rather than by engraftment. However, the complete absence of teratoma formation suggests that tumorigenic stem cells are dying or are killed in xenogeneic hosts, even if some cells that differentiate in vivo might survive.

\section{Effects of immunosuppressive treatment of recipients}

In many studies, immunosuppressive drugs, mostly CsA at doses between 10 and $20 \mathrm{mg} / \mathrm{kg} /$ day, were used to avoid the rejection of pluripotent stem cells transplanted to evaluate the therapeutic potential of these cells. However, little is known on the effects of cyclosporine A or other immunosuppressive drugs on engraftment, tumorigenicity, or differentiation of transplanted pluripotent stem cells.

In one study, the therapeutic effect of very low doses of undifferentiated mouse ESCs was evaluated in a rat model of Parkinson's disease [105]. As few as $2 \times 10^{3}$ to $4 \times 10^{3} \mathrm{D} 3$ ESCs were transplanted into the striatum of 6hydroxydopamine (OHDA)-lesioned rats resulting in teratomas in 5 out of 25 recipients. In other animals, the ESCs developed into dopaminergic neurons and a functional improvement of disease symptoms was reported. These rats received an immunosuppressive treatment with $15 \mathrm{mg} / \mathrm{kg} /$ day CsA. In a similar approach in a neurotrauma model, SpragueDawley rats were injected with $1 \times 10^{5}$ D3 mouse ESCs and two of ten animals developed tumors [106]. One of these was characterized as a chondroma. These animals received $10 \mathrm{mg} / \mathrm{kg} / \mathrm{day}$ CsA. The transplantation of the same ESCs into intact rat brains resulted in teratomas or teratocarcinomas in five out of eight animals within 2 weeks [107], suggesting that the inflammatory response to tissue damage in a disease model can alleviate the rejection of tumorigenic cells. Interestingly, the transplantation of $5 \times 10^{6}$ D 3 ESCs into the infarcted hearts of Sprague-Dawley rats resulted in teratomas in $80 \%$ of the recipients, which were immunosuppressed with CsA $(10 \mathrm{mg} / \mathrm{kg} /$ day $)$ and methylprednisolone ( $2 \mathrm{mg} / \mathrm{kg} /$ day) [108]. It would be worthwhile to investigate whether an additional anti-inflammatory therapy could increase the tumor risk. Human ESCs can also result in tumors when transplanted into the brain of CsA-treated 6-OHDA-lesioned rats [45]. Injection of $5 \times 10^{5} \mathrm{H} 1$ or H9 
human ESCs into the striatum of CsA-treated (15 to $20 \mathrm{mg} / \mathrm{kg} /$ day) Sprague-Dawley rats resulted in highly undifferentiated tumor masses within 4 weeks. Similarly, the injection of $3 \times 10^{6}$ or $1.5 \times 10^{6}$ human ESCs into healthy or infarcted hearts of CsA-treated rats $(15 \mathrm{mg} / \mathrm{kg} /$ day $)$ resulted in teratoma-like structures [109].

Low numbers of mouse $\operatorname{ESCs}\left(4 \times 10^{2}\right.$ to $\left.4 \times 10^{3}\right)$ were reported to generate neurons after transplantation into the brain of CsA-treated allogeneic recipients without teratoma formation, at least within 14 days [110]. Presumably, allogeneic mouse iPSCs $\left(5 \times 10^{5}\right)$ formed teratomas preferentially in ischemic compared to sham-operated brains of C57BL/6 mice treated with CsA (10 mg/kg/day) [111]. Notably, $0.5 \times 10^{6}$ to $1 \times 10^{6}$ maGSCs injected into the normal heart of partially allogeneic C57BL/6 mice (treated with $10 \mathrm{mg} / \mathrm{kg}$ CsA per day) were found to proliferate and to differentiate but not to form tumors within 1 month after transplantation [8]. Erdö and colleagues transplanted $129 \mathrm{~Sv}$-derived D3 ESCs $\left(\mathrm{H} 2^{\mathrm{b}}\right)$ into the striatum of $129 \mathrm{~Sv}$ $\left(\mathrm{H} 2^{\mathrm{b}}\right)$ or $\mathrm{C} 57 \mathrm{BL} / 6\left(\mathrm{H} 2^{\mathrm{b}}\right)$ recipients, in some of which a focal brain ischemia had been elicited [27]. The numbers of transplanted cells varied between 500 and $5 \times 10^{4}$ but tumors developed at high frequency in all experimental groups ( $75 \%$ to $100 \%$ of the recipients). The tumors were characterized as highly malignant and invasive teratocarcinomas. The tumorigenesis was independent of the location of implantation, presence or absence of immunosuppression, gender, age, and strain of the mice but these results were not shown in detail [27]. Notably, tumor risk in xenogeneic recipients, i.e., Wistar rats, was very low. Only 2 of 32 rats developed small tumors near the place of implantation [27]. Interestingly, the xenotransplantation to the hemisphere opposite to the ischemic brain injury resulted in migration towards the lesion and differentiation into neuronal cells in the boarder zone of the lesion [27]. Thus, in the setting of a xenotransplantation combined with immunosuppression by $\mathrm{CsA}$, the immune system might still contribute to the eradication of tumorigenic cells but allow a therapeutic effect of in vivo differentiated non-tumorigenic cells.

In an approach of comparing various immunogenetic settings, we evaluated teratoma growth in CsA-treated hosts and untreated controls [61]. After subcutaneous injection of $1 \times 10^{6}$ MPI-II ESCs $\left(\mathrm{H} 2^{b}\right)$ into syngeneic $\left(129 \mathrm{~Sv} \mathrm{H} 2^{b}\right)$, allogeneic $\left(\mathrm{C} 57 \mathrm{BL} / 6, \mathrm{H} 2^{\mathrm{b}}\right.$ and $\mathrm{C} 3 \mathrm{H} / \mathrm{HeN}, \mathrm{H} 2^{\mathrm{k}}$ ) and xenogeneic (LOU/c rats, $\mathrm{RT} 1^{\mathrm{u}}$ ) recipients, the frequency of teratomas was mainly unaffected by CsA at a dose of $10 \mathrm{mg} / \mathrm{kg} /$ day (Table 1). Only the syngeneic recipients developed teratomas with exception of 1 out of $15 \mathrm{CsA}$ treated allogeneic $\mathrm{C} 3 \mathrm{H} / \mathrm{HeN}$ recipients, in which a very small tumor was observed [61].

Swijnenburg and colleagues compared the effects of different classes of immunosuppressive drugs represented by tacrolimus, sirolimus, and mofetil on the survival of human ESCs after intramuscular injection into BALB/c mice [77]. The transplanted cells were rejected within 10 days in all single drug treatment groups and only a combination of tacrolimus and sirolimus extended cell survival to day 28 [77]. Interestingly, it was shown in another study that human ESCs form teratomas in the testis (not in the heart) of C57BL/6 mice just after transient blockade of co-stimulatory signals (CD40L, CTLA-4, and LFA-1) [73].

In conclusion, immunosuppressive treatment might increase the risk of teratoma formation after pluripotent stem cell transplantation at least in some experimental models. However, systematic studies evaluating the effects of immunosuppressive treatment and comparing the currently available immunosuppressive drugs in the context of pluripotent stem cell transplantation are largely lacking.

\section{Tumor risk after transplantation of in vitro-differentiated cells}

In many studies, pluripotent stem cells were differentiated before transplantation in order to avoid tumor formation. Some used immunodeficient mouse models to determine the tumor risk of pre-differentiated cells. Hentze and colleagues compared the teratoma growth of undifferentiated human ESCs with in vitro-differentiated cardiomyocytes and beta cells after intramuscular injection into SCID mice and found that the growth kinetics of teratomas were similar [44]. Others studies investigated differentiated cell populations only and reported a high risk of teratoma formation [112, 113]. A purity of 99.8\% insulin-positive cells derived from mouse ESCs was not sufficient to prevent teratoma growth in NOD/SCID mice that were transplanted to treat diabetes [112]. Recently, neuronal cells differentiated in vitro from a large number of iPSC clones were transplanted into the brain of NOD/SCID mice. It turned out that the teratoma risk substantially varied dependent on the tissue that was used to generate the iPSCs [114]. This might reflect the genetic variation of iPSC lines [29-31].

Interestingly, ESC-derived haematopoietic cells could be rejected in $\mathrm{Rag} 2^{-/-}$hosts, while the cells could engraft Rag2 $2^{-1-}$ c $\gamma \mathrm{c}^{-/-}$mice, in which in addition to $\mathrm{T}$ and $\mathrm{B}$ cells also NK cells are deleted [115, 116]. Similarly, the engraftment of NOD/SCID mice with human ESC-derived haematopoietic cells was improved by antibody-mediated NK cell depletion [71]. The transplantations of ESCderived vascular progenitors indicated that NK cells can also play a role in the rejection of these progenitor cells in syngeneic recipients [117]. In all these studies, no teratomas 
were found but they demonstrate that the ESC-derived progenitor cells can be rejected by elements of the innate immune system, such as NK cells. Moreover, also human neural progenitor cells were demonstrated to be efficiently killed by NK cells [118], suggesting that this problem is also relevant for human ESC-derived progenitor cells.

Robertson and colleagues transplanted embryoid body (EB)-derived cells under the kidney capsule of various recipients [65]. Syngeneic transplantations resulted in teratomas, whereas fully allogeneic cells were eventually rejected similarly to EBs with a single foreign MHC class I locus and EBs that differed only in minor histocompatibility antigens. The rejection was associated with a substantial inflammatory response. In a subsequent study, male ESC-derived EBs $\left(\mathrm{CBK}, \mathrm{H} 2^{\mathrm{k}}\right)$ with a single $\mathrm{MHC}$ mismatch $\left(\mathrm{K}^{\mathrm{b}}\right)$ were shown to be accepted in $50 \%$ of male hosts $\left(\mathrm{CBK}, \mathrm{H} 2^{\mathrm{k}}\right)$ for 28 days, but rejected in all female recipients at that time point, suggesting a role of $\mathrm{H}-\mathrm{Y}$ antigens in the rejection of EBs [119].

Also, other studies reported a high risk of teratoma formation after transplantation of ESC-derived differentiated cell populations into syngeneic hosts. Transplantation of $6 \times 10^{4}$ differentiated cells $(90 \%$ positive for the neuronal marker nestin) into the subretinal space resulted in teratomas in $50 \%$ of the syngeneic recipients within 2 months after transplantation [80]. However, the tumor risk appears to depend on the purity of the differentiated cell population. Highly purified cardiomyocytes ( $>99 \%$ pure) transplanted into the myocardium of syngeneic mice formed no teratomas. However, in 3 out of 60 recipients malignant fibrous histiocytomas were found [36].

Very interesting results were obtained by $\mathrm{Wu}$ and colleagues [89]. They transplanted ESC-derived insulinproducing cell clusters into diabetic immunodeficient $\mathrm{RAG1}^{-/-}$mice and achieved normoglycemia for several days. The grafts failed to activate adoptively transferred alloreactive TCR-transgenic BM3 CTLs likely due to the absence of donor APCs in the grafts. Nonetheless, the grafts were rapidly rejected in allogeneic and even syngeneic immunocompetent recipients. Thus, the ESC-derived grafts might express novel immunogenic antigens that are not present in the adult organism so that no tolerance has been established. The effects of NK cells have also to be taken into consideration in this model.

Further reports on the outcome of allogeneic transplantations of in vitro-differentiated cells indicate a high variability. Even early differentiated cells were reported to engraft without forming teratomas in a model of myocardial infarction [120]. Again, the possibility should not be dismissed that tumorigenic cells might be killed more efficiently in an inflamed tissue compared to models evaluating transplantations into intact organs. It has been concluded from a murine model of myocarditis, in which no tumors were observed, that inflammation might have further beneficial effects on homing, differentiation, and integration of intravenously administered allogeneic ESCs [121]. Endodermal precursor cells differentiated from ESCs of $129 \mathrm{~Sv}$ mice $\left(\mathrm{H}^{\mathrm{b}}\right)$ were evaluated for their ability to correct a factor IX deficiency in C57BL/6 mice $\left(\mathrm{H}^{2}{ }^{\mathrm{b}}\right)$ and fully allogeneic BALB/c mice $\left(\mathrm{H}^{\mathrm{d}}\right)$. In minor histoincompatible C57BL/6 recipients, 6 out of 64 mice $(9 \%)$ developed teratomas and in minor plus major histoincompatible BALB/c mice 1 out of 18 (6\%) [122]. Swijnenburg and colleagues reported that pre-differentiated mouse ESCs were more rapidly rejected in allogeneic hosts than undifferentiated ESCs [88].

In vitro pre-differentiation of mouse and human ESCs has been successful in several xenograft models, in which no tumors were observed after transplantation into CsA-treated recipients [45, 109, 123-128] or into nude rats [129]. However, teratoma formation was reported in some studies to depend on the duration of in vitro differentiation of the transplanted cells [33] or on the immunosuppressive treatment of the recipients [130]. Others have even indicated graft rejection without therapeutic effects: Transplantation of cardiac-committed mouse ESCs into infarcted baboon hearts, e.g., resulted in graft rejection likely mediated by $\mathrm{T}$ lymphocytes and NK cells [131].

Notably, ESC-derived xenografts transplanted into an immune-privileged organ, such as the brain, can survive without immunosuppression. This was shown by Baier and colleagues [132] who transplanted dopaminergic neurons, differentiated in vitro for 14 days on PA6 feeder cells, into the striatum of unilaterally 6-OHDA-lesioned rats. The grafted cells survived in the absence of immunosuppression for at least 5 weeks after transplantation, although they showed no signs of morphological integration into the host tissue. Nonetheless, the transplantation improved the rotational behavior of the rats, serving as model of Parkinson's disease [132]. When the recipients were treated with CsA, the morphological integration appeared to be improved, but now 2 of 15 recipients developed teratomas [130]. Although the reduction of tumor risk is one of the major aims of in vitro differentiation of stem cell grafts, a systematic comparison of teratoma formation after transplantation of undifferentiated and differentiated cells has rarely been performed.

The results reported by Baier [132] and Thinyane [130] prompted us to analyze the tumorigenicity of undifferentiated ESCs and in vitro-differentiated neuronal cells in more detail [61]. Similar numbers $\left(1 \times 10^{6}\right)$ of undifferentiated MPI-II ESCs $\left(\mathrm{H} 2^{\mathrm{b}}\right)$ and neuronal cells differentiated in vitro were subcutaneously injected into immunodeficient SCID/beige, syngeneic $\left(129 \mathrm{~Sv} \mathrm{H} 2^{\mathrm{b}}\right)$, 
allogeneic $\left(\mathrm{C} 57 \mathrm{BL} / 6, \mathrm{H} 2^{\mathrm{b}}\right.$, and $\mathrm{C} 3 \mathrm{H} / \mathrm{HeN}, \mathrm{H} 2^{\mathrm{k}}$ ) and xenogeneic $\left(\mathrm{LOU} / \mathrm{c}\right.$ rats, $\left.\mathrm{RT}^{\mathrm{u}}{ }^{\mathrm{C}}\right)$ recipients. The immunocompetent animals were either treated with CsA $(10 \mathrm{mg} / \mathrm{kg} /$ day) or not (Table 1$)$. About $95 \%$ of the cells from the differentiation cultures were positive for the neuronal marker Tuj1 and $30 \%$ of the neurons were positive for tyrosine hydroxylase indicating a dopaminergic differentiation $[61,132]$. Less than $5 \%$ of the colonies in the differentiation cultures contained OCT3/4 and Ki67positive cells, which might represent still undifferentiated ESCs [61]. Teratomas were detected in immunodeficient and syngeneic recipients after injection of undifferentiated as well as differentiated cells at a similar high frequency of about $95 \%$ and with similar growth kinetics in contrast to allogeneic or xenogeneic recipients (Table 1). Such a finding is usually attributed to the contamination of in vitro-differentiated cell populations with still undifferentiated ESCs [40], although it was under this assumption surprising that teratoma growth was not markedly decelerated in mice injected with the differentiated cell population. However, this view was challenged by the results obtained in CsA-treated recipients (Table 1). Syngeneic recipients still developed teratomas and in allogeneic mice very small tumors were observed in single cases. The surprising finding was a high incidence (61\%) of rapidly growing teratomas in CsA-treated rats after injection of differentiated cells (containing clearly less than $5 \%$ ESCs) in contrast to pure undifferentiated ESCs [61] (Table 1). This finding indicates the existence of a cell type in the differentiation cultures different from ESCs that is still pluripotent and can give rise to teratomas. This cell population is apparently not tumorigeneic in immunocompetent rats because animals that were not treated with CsA did not develop teratomas. Importantly, the undifferentiated ESCs were not tumorigenic even in CsAtreated recipients. Thus, the immune control of this putative pluripotent cell type present in differentiation cultures might depend on $\mathrm{T}$ cells that were inhibited by CsA. The undifferentiated ESCs, in contrast, can apparently be controlled sufficiently by immune mechanisms that are not inhibited by CsA. We found evidence for a high activity of NK cells in rats that kill the undifferentiated ESCs but not the in vitro-differentiated cells [61]. These data suggest that a cell type can occur in differentiation cultures, which already lost susceptibility to innate immune mechanism, such as NK cells, but still is pluripotent and tumorigenic (Fig. 2). It remains to be elucidated whether only the ESC line and differentiation procedure evaluated in our study [61] generates those cells or whether this is a more general phenomenon. Interestingly, Preynat-Seauve and colleagues recently reported that the NK cell-mediated killing of human ESC-derived neural progenitor cells was not inhibited by CsA in contrast to further differentiation of progenitors into neurons [118]. Thus, an escape from NK cell killing by differentiation into NK cell resistant neurons might be inhibited by CsA.

In conclusion, the immune system of recipients appears to contribute to the control of tumorigenicity of stem cellderived transplants. Apparently, not only completely undifferentiated stem cells can give rise to teratomas and various tumorigenic cell types appear to be rejected preferentially by different immune mechanisms.

\section{Immune effector mechanisms contributing to the rejection of pluripotent stem cell-derived teratomas}

Several immune effector mechanisms appear to be important for the rejection of pluripotent stem cell-derived teratomas, including $\mathrm{T}$ cells [67], NK cells [61, 71, 75], and the complement system [59]. Different effector mechanisms might be important for the recognition and elimination of pluripotent stem cells and cells that differentiate from stem cells either in vitro before or in vivo after transplantation. The cells differentiated in vitro from ESCs were found to be less susceptible to killing by NK cells [61, 133] and the alternative complement pathway [59] than undifferentiated ESCs. Other experiments suggest that recognition by $\mathrm{T}$ cells increases with differentiation [60, $81,90]$ suggesting a negative effect of the adaptive immune system on engraftment of differentiated cells. The efficacy of these various effector mechanisms in suppression of tumors and graft rejection presumably differs dependent on the immunogenetic setting of transplantations, whether it is, e.g., a syngeneic, allogeneic, or xenogeneic transplantation. Some of these effector mechanisms are profoundly suppressed by immunosuppressive treatment with drugs, such as CsA, but others are not.

Several studies suggest that CTLs play a major role in the rejection of teratomas derived from pluripotent stem cells $[88,89,93,119]$. The recognition structures for CTLs on target cells, the polymorphic MHC class I molecules, are assumed to represent the most important immunological barrier for transplantation of pluripotent stem cell-derived allografts [134, 135]. The MHC class I molecules are targets for alloreactive CTLs either by direct or indirect allorecognition [134, 135] but minor histocompatibility antigens, which are presented by MHC class I molecules, have also been shown to contribute to the rejection of ESCderived grafts by CTLs [61, 65, 119]. However, in a xenotransplantation of human ESCs into murine hosts direct allorecognition by CTLs might be less relevant due to a lower affinity of mouse TCRs to human MHC class I molecules. Instead indirect allorecognition by $\mathrm{CD}^{+}$helper 
Fig. 2 Schematic representation of factors which influence the outcome of pluripotent stem cell transplantations. Besides graftrelated factors, such as pluripotency and therapeutic efficacy, host-related factors in first line immune-mediated rejection mechanisms have to be taken into consideration to understand the outcome of transplantations of pluripotent stem cells or their differentiation products. Possible outcomes include rejection, engraftment, teratoma formation, or growth of lineagerestricted tumors. Host factors presumably explain some of the variations observed with different cell types in different experimental transplantation models

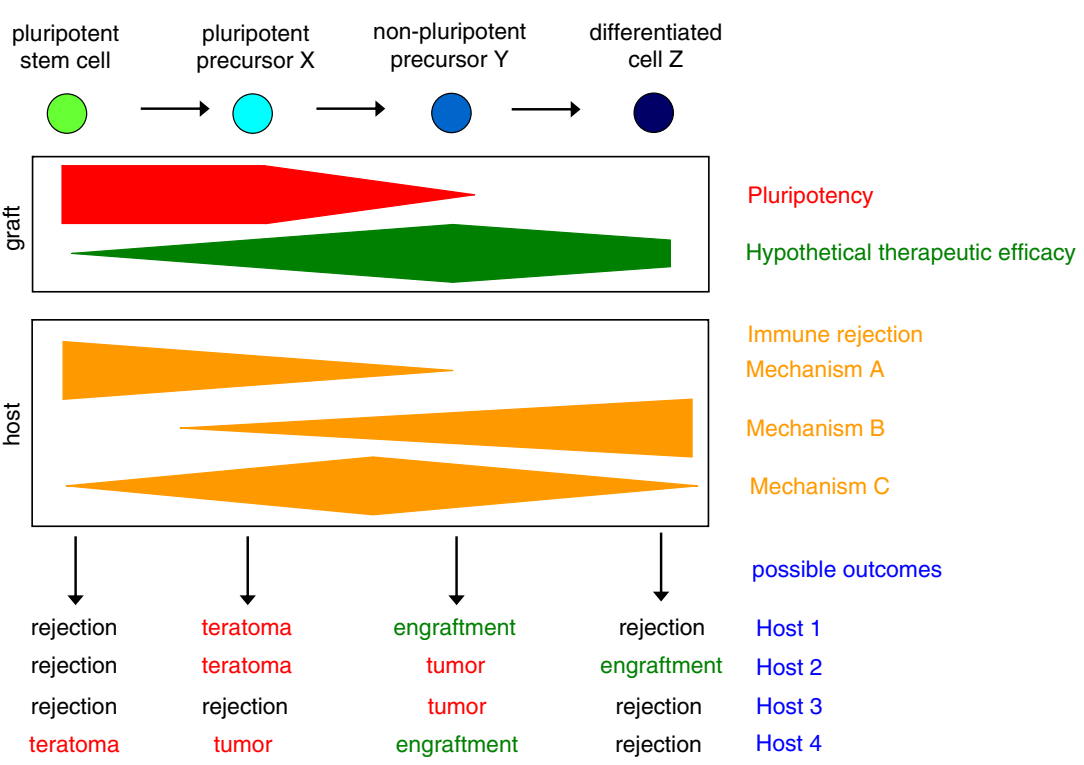

$\mathrm{T}$ cells was reported to be more important for the rejection of human ESCs by mouse recipients [77].

Notably, MHC class I molecules are not detectable by flow cytometry on mouse ESCs $[11,58,60,61,75,89$, 94, $133,136,137]$ and other pluripotent mouse stem cell types including maGSCs and iPSCs [11, 75]. Despite being negative for MHC class I molecules, we analyzed a number of pluripotent mouse stem cell lines, including two ESC lines, two maGSC lines, and one iPSC line, for susceptibility to killing by CTLs. All tested stem cell lines were readily killed in a peptide-dependent manner by activated CTLs derived from TCR-transgenic OT-I mice that recognize the peptide SIINFEKL in the context of $\mathrm{H} 2 \mathrm{~K}^{\mathrm{b}}$ molecules, although less efficiently than RMA lymphoma cell used as positive control [11]. This finding is in accordance with studies showing that extremely low numbers of MHC molecules on target cells are sufficient for CTL recognition and killing [138-140]. In contrast to our findings, Abdullah and colleagues reported that the recognition of CGR8 ESCs by CTLs is not sufficient for killing due to the expression of serpin SPI-6 [137, 141], which is an endogenous inhibitor of granzyme B [142]. However, all pluripotent stem cell lines that we analyzed were uniformly negative for SPI-6 and susceptible to CTL killing mediated in the granule exocytosis pathway [11, 75]. Activated alloreactive CTLs were reported to modestly kill IFN- $\gamma$ treated [94] but not untreated RW-4 ESCs [143]. Thus, pluripotent stem cell lines are not generally immuneprivileged due to low expression of MHC class I molecules and resistance to CTL-mediated killing, although different cell lines might vary considerably. It remains to be analyzed whether pluripotent stem cells can process endogenous antigens for presentation on MHC class I molecules. If so, peptides derived from proteins that are exclusively expressed in pluripotent stem cells, such as OCT3/4 or NANOG, might function as tumor antigens.

Importantly, the expression of MHC class I molecules has been reported to increase during in vitro [144] or in vivo differentiation of mouse ESCs [65, 88-90, 93]. Furthermore, MHC class I molecules are inducible by IFN- $\gamma$ in mouse ESCs $[89,94]$ and human ESCs [145] or in differentiated cells $[118,133,137]$ and IFN- $\gamma$ and other pro-inflammatory cytokines are present in at least some transplantation models associated with inflammation [90, 119]. Thus, ESCs and their differentiation products might become even better targets for CTLs after transplantation of differentiated cells or in vivo differentiation $[60,65,81$, 89]. Human ESCs, in contrast to mouse ESCs, were shown to express low but in flow cytometry detectable levels of MHC class I molecules [144-146] and reported to be susceptible to killing by human CTLs [76]. Human ESCderived neural progenitor cells were able to induce allogeneic $\mathrm{T}$ cell proliferation especially after treatment with IFN- $\gamma$, which induces expression of MHC class I molecules [118].

MHC class I molecules are not only antigen-presenting molecules and recognition structures for CTLs. They function also as ligands for inhibitory NK receptors and prevent the killing of uninfected and non-malignant cells by NK cells [147]. The "missing self" concept implies that cells lacking MHC class I molecules due to virus infection or malignant transformation become targets for $\mathrm{NK}$ cells [148]. Thus, it was surprising that ESCs were reported to be resistant to NK cells $[93,94]$ or only very moderately killed by activated NK cells [94]. We found that unstimulated rat NK cells readily killed mouse ESCs and that IL-2-activated syngeneic and allogeneic mouse NK cells also killed ESC targets $[61,75]$. This appears to be a regular phenotype of 
pluripotent stem cells because all pluripotent mouse stem cell lines that we investigated, including four ESC lines, four maGSC lines, and one iPSC line, were highly susceptible targets for activated NK cells derived from syngeneic, allogeneic, and xenogeneic donors; some of them were even better killed than the conventional NK target cell line YAC-1 [75]. In accordance with these data, four other ESC lines were also reported to be killed by activated mouse NK cells although less efficiently than YAC-1 cells [133].

The cytotoxic activity of NK cells is not only controlled by inhibitory receptors recognizing MHC class I molecules but also by a diverse set of activating receptors that recognize specific ligands on targets. Most mouse pluripotent stem cell lines appear to express some ligands for activating NK receptors and most frequently ligands for the activating receptor NKG2D [61, 75, 133]. The recognition of these ligands by NK cells is known to trigger cytotoxicity [149]. Normally, NKG2D ligands are not expressed on healthy cells but they can become induced by conditions, such as heat shock [150], virus infection [151], or genotoxic stress [152]. The NKG2D ligands appear to signal the presence of potentially dangerous cells to the immune system [153] and they contribute to tumor immune surveillance [149]. NKG2D ligands are a heterogeneous group of molecules consisting in the mouse of the RAE-1 family, MULT-1, and H60 proteins [149]. The NKG2D ligands found to be expressed on pluripotent stem cell lines belong to the RAE-1 family only [61, 75]. Interestingly, the RAE-1 molecules were initially cloned from pluripotent F9 teratocarcinoma cells [154] that are also highly susceptible to killing by NK cells $[75,155$, 156]. The functional relevance of NKG2D ligands could be demonstrated by inhibition of NK cell-mediated stem cell killing by soluble NKG2D molecules [61, 75]. RW-4 mouse ESCs have also been reported to express RAE-1 molecules but to trigger only a modest cytotoxicity of activated NK cells [94]. However, since it was reported that ICAM-1 expression on ESCs is critical for NK cellmediated killing [133], the presence of RAE-1 molecules must not be sufficient to trigger lysis. In addition to NKG2D ligands, many pluripotent stem cell lines express CD112 and CD155 [75], the ligands of the activating NK receptor DNAM-1 (CD226) [157]. These ligands were also reported recently to be important for the killing of stem cell-like glioblastoma cells by NK cells [158]. In our set of pluripotent mouse stem cell lines, we found no ligands of the NK receptors 2B4 and NKp46 to be expressed. The lack of NKp46 ligands on ESCs is in accord with another report [133]. Human ESCs have been shown to express small amounts of ligands for the activating NK receptor NKp44 and to be killed moderately by human NK cells [146]. Human ESCs were recently shown also to express low levels of MICA and MICB human ligands for NKG2D [159]. Human ESC-derived neural progenitors cells have been reported also to express MICA and MICB as well as the NKG2D ligands ULBP-1, 2, and 3 [118]. These cells were killed by IL-15-stimulated NK cells in an NKG2Ddependent manner [118]. Thus, a set of ligands for activating NK receptors, in addition to absence of ligands of inhibitory NK receptors, can determine the susceptibility of pluripotent stem cell lines to NK cells and every cell line appears to have a specific expression pattern of such ligands [75]. Moreover, it has been shown that the transplantation of ESCs can give rise to antibodies that bind to cell surface molecules on ESCs [90]. Therefore, antibody-dependent cellular cytotoxicity, mediated by NK cells or other effectors, could likely also contribute to the rejection of stem cell grafts.

Notably, in vitro differentiation of stem cell lines increases resistance to $\mathrm{NK}$ cells $[61,75,133]$. The resistance of differentiated neuronal cells [61], cardiomyocytes [133], or mixed cell populations [75] correlated with the downregulation of NKG2D ligands on these cells much better than with increased expression of MHC class I molecules that serve as ligands for inhibitory NK receptors. However, in one study, an upregulation of the NKG2D ligand $\mathrm{H} 60$ on ESCs-derived hematopoietic progenitors was observed resulting in lysis of these progenitors by NK cells [116]. Notably, the differentiated cells, in contrast to ESCs, were also reported to be resistant to the alternative antibody-independent complement pathway [59].

In conclusion, all immune effector mechanisms, which have been explored in some detail, can apparently contribute to the rejection of pluripotent stem cells or stem cell-derived grafts under certain conditions. This includes effector functions of the adaptive and innate immune system. Transplanted cells types, such as undifferentiated pluripotent stem cells, precursor cell populations, or various terminally differentiated cell types can differ in their susceptibility to these immune effector mechanisms. Notably, variations might be exploitable to suppress tumorigenic cells while allowing for engraftment of therapeutically active cells.

\section{Immune-privileged and immunosuppressive versus immunogenic properties of pluripotent stem cells and pluripotent stem cell-derived grafts}

Several studies have suggested that mouse or human ESCs have immune-privileged [67, 93, 94, 137, 146], immunosuppressive [91, 93, 94, 119, 145], or tolerance-inducing [143] properties. They may suppress immune responses by contact dependent and contact independent mechanisms, including production of immunosuppressive cytokines, 
such as transforming growth factor (TGF)- $\beta[65,93]$ and interleukin (IL)-10 [119], depletion of amino acids, such as L-agrinine that are required for $\mathrm{T}$ cell activation [91], or induction of apoptosis in alloreactive $\mathrm{T}$ cells via FasL on ESCs [94, 143]. It has been suggested that tolerance might be more easily achievable for ESC-derived grafts because TGF- $\beta$ favors the polarization of infiltrating T cells toward a regulatory phenotype $[65,119]$. However, in another study, tolerance against subsequent allografts was not achieved by ESC transplantation [93].

Meanwhile, it has become clear from several studies that allogeneic pluripotent stem cells are frequently rejected [60, $81,90]$, although their destruction might be delayed because the immunogenicity of transplanted cells increases upon differentiation in vivo $[60,81]$ or immunosuppressive effects of ESCs are transiently effective [65, 91, 119]. Notably, the transplantation of pluripotent stem cells can induce an immunological memory. The rejection of the $129 \mathrm{~Sv}-$ derived D3 ESCs was accelerated in BALB/c mice that were presensitized with the ESCs [88]. Similarly, ESCs were shown to sensitize the recipients leading to an accelerated rejection of a subsequent skin allograft. Interestingly, this was observed only in animals that rejected the ESCs and not in animals in which teratomas were formed [93].

Nonetheless, pluripotent stem cell-derived grafts are presumably less immunogenic than conventional allografts due to low expression of MHC class I molecules, lack of professional APCs, failure to stimulate a direct alloresponse, and further more specific mechanisms. However, this low immunogenicity appears to be fragile and can rather easily be overcome [89]. Importantly, numerous studies have shown that pluripotent stem cell or their derivatives are at risk to form tumors after syngeneic, allogeneic, and even xenogeneic transplantations. It will be worthwhile to further determine to which extent the immunosuppressive mechanisms of pluripotent stem cells contribute to this unwanted outcome.

\section{Conclusions}

Pluripotent stem cells clearly hold great promises for the replacement of diseased cells and tissues by transplantation of stem cells or, more likely, their in vitro-generated derivatives. However, pluripotency and tumorigenicity are closely related features of stem cells. Therefore, the risk of tumor formation must be resolved before clinical application of any kind of pluripotent stem cell therapy. Numerous studies have shown that pluripotent stem cells can form teratomas and other tumors in immunodeficient, syngeneic, allogeneic, and even xenogeneic recipients, depending on the conditions of transplantation. However, the immune system of the recipient does not only has profound effects on engraftment of stem cell-derived transplants but also on tumor formation (Fig. 2). The innate immune system, e.g., NK cells and complement system, appears to be able to reject smaller numbers of pluripotent stem cells even in some immunodeficient and, importantly, in immunocompetent syngeneic recipients. The innate and adaptive immune mechanisms apparently can also impair engraftment of syngeneic stem cell transplants. This should be noted for future autologous pluripotent stem cell therapies, making use of iPSCs, which soon might become available for regenerative medicine. Notably, this might be even of advantage, if the immune system of immunocompetent recipients can be exploited to preferentially kill tumorigenic cells, which contaminate grafts in trace amounts despite all efforts to reduce their numbers before transplantation. Since pluripotent stem cells might not be used solely in autologous settings, it will be important to carefully analyze alloimmune responses against tumorigenic as well therapeutically beneficial stem cell derivatives in models representing the various possible immungenetic scenarios. Variations in the immune response against undifferentiated pluripotent stem cells, precursor cell populations, or terminally differentiated cell types in immunocompetent or immunosuppressed recipients can apparently determine the outcome of experimental transplantations with respect to engraftment and tumor development. This has to be taken into account to correctly interpret the results of therapy models and for future translation into clinical practice.

Acknowledgments This work was supported by grant 01GN0819 from the German Federal Ministry for Research and Technology (BMBF). I would like to thank Leslie Elsner, Hannah Johansen, Sebastian Monecke, and Peter Novota, who contributed to the stem cell-related work in my research group. Moreover, I am grateful to my collaborators Paul Christian Baier, Michael Didié, Wolfgang Engel, Kaomei Guan, Gerd Hasenfuss, Rudolf Jaenisch, Tanja Kuhlmann, Ahmed Mansouri, Vijayakumar Muppala, Karim Nayernia, Jessica Nolte, Walter Paulus, Jan Schindehütte, Katrin Streckfuss-Bömecke, Claudia Trenkwalder, and Wolfram-Hubertus Zimmermann for their support of our work on pluripotent stem cell transplantation immunology.

Open Access This article is distributed under the terms of the Creative Commons Attribution Noncommercial License which permits any noncommercial use, distribution, and reproduction in any medium, provided the original author(s) and source are credited.

\section{References}

1. Nishikawa S, Goldstein RA, Nierras CR (2008) The promise of human induced pluripotent stem cells for research and therapy. Nat Rev Mol Cell Biol 9:725-729

2. Takahashi K, Yamanaka S (2006) Induction of pluripotent stem cells from mouse embryonic and adult fibroblast cultures by defined factors. Cell 126:663-676 
3. Wernig M, Meissner A, Foreman R, Brambrink T, Ku M, Hochedlinger K, Bernstein BE, Jaenisch R (2007) In vitro reprogramming of fibroblasts into a pluripotent ES-cell-like state. Nature 448:318-324

4. Yu J, Vodyanik MA, Smuga-Otto K, Antosiewicz-Bourget J, Frane JL, Tian S, Nie J, Jonsdottir GA, Ruotti V, Stewart R, Slukvin II, Thomson JA (2007) Induced pluripotent stem cell lines derived from human somatic cells. Science 318:1917-1920

5. Meissner A, Wernig M, Jaenisch R (2007) Direct reprogramming of genetically unmodified fibroblasts into pluripotent stem cells. Nat Biotechnol 25:1177-1181

6. Kanatsu-Shinohara M, Inoue K, Lee J, Yoshimoto M, Ogonuki N, Miki H, Baba S, Kato T, Kazuki Y, Toyokuni S, Toyoshima M, Niwa O, Oshimura M, Heike T, Nakahata T, Ishino F, Ogura A, Shinohara T (2004) Generation of pluripotent stem cells from neonatal mouse testis. Cell 119:1001-1012

7. Guan K, Nayernia K, Maier LS, Wagner S, Dressel R, Lee JH, Nolte J, Wolf F, Li M, Engel W, Hasenfuss G (2006) Pluripotency of spermatogonial stem cells from adult mouse testis. Nature 440:1199-1203

8. Guan K, Wagner S, Unsöld B, Maier LS, Kaiser D, Hemmerlein B, Nayernia K, Engel W, Hasenfuss G (2007) Generation of functional cardiomyocytes from adult mouse spermatogonial stem cells. Circ Res 100:1615-1625

9. Streckfuss-Bömeke K, Vlasov A, Hülsmann S, Yin D, Nayernia K, Engel W, Hasenfuss G, Guan K (2008) Generation of functional neurons and glia from multipotent adult mouse germ-line stem cells. Stem Cell Res 2:139-154

10. Glaser T, Opitz T, Kischlat T, Konang R, Sasse P, Fleischmann BK, Engel W, Nayernia K, Brüstle O (2008) Adult germ line stem cells as a source of functional neurons and glia. Stem Cells 26:2434-2443

11. Dressel R, Guan K, Nolte J, Elsner L, Monecke S, Nayernia K, Hasenfuss G, Engel W (2009) Multipotent adult germ-line stem cells, like other pluripotent stem cells, can be killed by cytotoxic $\mathrm{T}$ lymphocytes despite low expression of major histocompatibility complex class I molecules. Biol Direct 4:31

12. Conrad S, Renninger M, Hennenlotter J, Wiesner T, Just L, Bonin M, Aicher W, Buhring HJ, Mattheus U, Mack A, Wagner HJ, Minger S, Matzkies M, Reppel M, Hescheler J, Sievert KD, Stenzl A, Skutella T (2008) Generation of pluripotent stem cells from adult human testis. Nature 456:344-349

13. Kossack N, Meneses J, Shefi S, Nguyen HN, Chavez S, Nicholas C, Gromoll J, Turek PJ, Reijo-Pera RA (2009) Isolation and characterization of pluripotent human spermatogonial stem cell-derived cells. Stem Cells 27:138-149

14. Golestaneh N, Kokkinaki M, Pant D, Jiang J, DeStefano D, Fernandez-Bueno C, Rone JD, Haddad BR, Gallicano GI, Dym M (2009) Pluripotent stem cells derived from adult human testes. Stem Cells Dev 18:1115-1126

15. Ko K, Arauzo-Bravo MJ, Tapia N, Kim J, Lin Q, Bernemann C, Han DW, Gentile L, Reinhardt P, Greber B, Schneider RK, Kliesch S, Zenke M, Schöler HR (2010) Human adult germline stem cells in question. Nature 465:E1

16. Blum B, Benvenisty N (2009) The tumorigenicity of diploid and aneuploid human pluripotent stem cells. Cell Cycle 8:3822-3830

17. Halme DG, Kessler DA (2006) FDA regulation of stem-cellbased therapies. N Engl J Med 355:1730-1735

18. Blum B, Benvenisty N (2008) The tumorigenicity of human embryonic stem cells. Adv Cancer Res 100:133-158

19. Anisimov SV, Morizane A, Correia AS (2010) Risks and mechanisms of oncological disease following stem cell transplantation. Stem Cell Rev 6:411-424

20. Fong CY, Gauthaman K, Bongso A (2010) Teratomas from pluripotent stem cells: a clinical hurdle. J Cell Biochem 111:769-781
21. Lensch MW, Schlaeger TM, Zon LI, Daley GQ (2007) Teratoma formation assays with human embryonic stem cells: a rationale for one type of human-animal chimera. Cell Stem Cell 1:253258

22. Müller FJ, Goldmann J, Loser P, Loring JF (2010) A call to standardize teratoma assays used to define human pluripotent cell lines. Cell Stem Cell 6:412-414

23. Brivanlou AH, Gage FH, Jaenisch R, Jessell T, Melton D, Rossant J (2003) Stem cells. Setting standards for human embryonic stem cells. Science 300:913-916

24. Brinster RL (1974) The effect of cells transferred into the mouse blastocyst on subsequent development. J Exp Med 140:10491056

25. Nagy A, Gocza E, Diaz EM, Prideaux VR, Ivanyi E, Markkula M, Rossant J (1990) Embryonic stem cells alone are able to support fetal development in the mouse. Development 110:815-821

26. Gertow K, Wolbank S, Rozell B, Sugars R, Andang M, Parish CL, Imreh MP, Wendel M, Ahrlund-Richter L (2004) Organized development from human embryonic stem cells after injection into immunodeficient mice. Stem Cells Dev 13:421-435

27. Erdö F, Buhrle C, Blunk J, Hoehn M, Xia Y, Fleischmann B, Focking M, Kustermann E, Kolossov E, Hescheler J, Hossmann KA, Trapp T (2003) Host-dependent tumorigenesis of embryonic stem cell transplantation in experimental stroke. J Cereb Blood Flow Metab 23:780-785

28. Damjanov I (1993) Teratocarcinoma: neoplastic lessons about normal embryogenesis. Int J Dev Biol 37:39-46

29. Hussein SM, Batada NN, Vuoristo S, Ching RW, Autio R, Narva E, $\mathrm{Ng} \mathrm{S}$, Sourour M, Hamalainen $\mathrm{R}$, Olsson $\mathrm{C}$, Lundin $\mathrm{K}$, Mikkola M, Trokovic R, Peitz M, Brustle O, Bazett-Jones DP, Alitalo K, Lahesmaa R, Nagy A, Otonkoski T (2011) Copy number variation and selection during reprogramming to pluripotency. Nature 471:58-62

30. Gore A, Li Z, Fung HL, Young JE, Agarwal S, AntosiewiczBourget J, Canto I, Giorgetti A, Israel MA, Kiskinis E, Lee JH, Loh YH, Manos PD, Montserrat N, Panopoulos AD, Ruiz S, Wilbert ML, Yu J, Kirkness EF, Izpisua Belmonte JC, Rossi DJ, Thomson JA, Eggan K, Daley GQ, Goldstein LS, Zhang K (2011) Somatic coding mutations in human induced pluripotent stem cells. Nature 471:63-67

31. Lister R, Pelizzola M, Kida YS, Hawkins RD, Nery JR, Hon G, Antosiewicz-Bourget J, O'Malley R, Castanon R, Klugman S, Downes M, Yu R, Stewart R, Ren B, Thomson JA, Evans RM, Ecker JR (2011) Hotspots of aberrant epigenomic reprogramming in human induced pluripotent stem cells. Nature 471:68-73

32. Knoepfler PS (2009) Deconstructing stem cell tumorigenicity: a roadmap to safe regenerative medicine. Stem Cells 27:1050-1056

33. Brederlau A, Correia AS, Anisimov SV, Elmi M, Paul G, Roybon L, Morizane A, Bergquist F, Riebe I, Nannmark U, Carta M, Hanse E, Takahashi J, Sasai Y, Funa K, Brundin P, Eriksson PS, Li JY (2006) Transplantation of human embryonic stem cell-derived cells to a rat model of Parkinson's disease: effect of in vitro differentiation on graft survival and teratoma formation. Stem Cells 24:1433-1440

34. Chung S, Shin BS, Hedlund E, Pruszak J, Ferree A, Kang UJ, Isacson O, Kim KS (2006) Genetic selection of sox1GFPexpressing neural precursors removes residual tumorigenic pluripotent stem cells and attenuates tumor formation after transplantation. J Neurochem 97:1467-1480

35. Fukuda H, Takahashi J, Watanabe K, Hayashi H, Morizane A, Koyanagi M, Sasai Y, Hashimoto N (2006) Fluorescenceactivated cell sorting-based purification of embryonic stem cellderived neural precursors averts tumor formation after transplantation. Stem Cells 24:763-771

36. Kolossov E, Bostani T, Roell W, Breitbach M, Pillekamp F, Nygren JM, Sasse P, Rubenchik O, Fries JW, Wenzel D, Geisen 
C, Xia Y, Lu Z, Duan Y, Kettenhofen R, Jovinge S, Bloch W, Bohlen H, Welz A, Hescheler J, Jacobsen SE, Fleischmann BK (2006) Engraftment of engineered ES cell-derived cardiomyocytes but not BM cells restores contractile function to the infarcted myocardium. J Exp Med 203:2315-2327

37. Klug MG, Soonpaa MH, Koh GY, Field LJ (1996) Genetically selected cardiomyocytes from differentiating embronic stem cells form stable intracardiac grafts. J Clin Invest 98:216-224

38. Schuldiner M, Itskovitz-Eldor J, Benvenisty N (2003) Selective ablation of human embryonic stem cells expressing a "suicide" gene. Stem Cells 21:257-265

39. Cao F, Lin S, Xie X, Ray P, Patel M, Zhang X, Drukker M, Dylla SJ, Connolly AJ, Chen X, Weissman IL, Gambhir SS, Wu JC (2006) In vivo visualization of embryonic stem cell survival, proliferation, and migration after cardiac delivery. Circulation 113:1005-1014

40. Bieberich E, Silva J, Wang G, Krishnamurthy K, Condie BG (2004) Selective apoptosis of pluripotent mouse and human stem cells by novel ceramide analogues prevents teratoma formation and enriches for neural precursors in ES cell-derived neural transplants. J Cell Biol 167:723-734

41. Choo AB, Tan HL, Ang SN, Fong WJ, Chin A, Lo J, Zheng L, Hentze H, Philp RJ, Oh SK, Yap M (2008) Selection against undifferentiated human embryonic stem cells by a cytotoxic antibody recognizing podocalyxin-like protein-1. Stem Cells 26:1454-1463

42. Hewitt Z, Priddle H, Thomson AJ, Wojtacha D, McWhir J (2007) Ablation of undifferentiated human embryonic stem cells: exploiting innate immunity against the Gal alpha1-3Galbeta14GlcNAc-R (alpha-Gal) epitope. Stem Cells 25:10-18

43. Lawrenz B, Schiller H, Willbold E, Ruediger M, Muhs A, Esser S (2004) Highly sensitive biosafety model for stem-cell-derived grafts. Cytotherapy 6:212-222

44. Hentze H, Soong PL, Wang ST, Phillips BW, Putti TC, Dunn NR (2009) Teratoma formation by human embryonic stem cells: evaluation of essential parameters for future safety studies. Stem Cell Res 2:198-210

45. Roy NS, Cleren C, Singh SK, Yang L, Beal MF, Goldman SA (2006) Functional engraftment of human ES cell-derived dopaminergic neurons enriched by coculture with telomeraseimmortalized midbrain astrocytes. Nat Med 12:1259-1268

46. Elkabetz Y, Panagiotakos G, Al Shamy G, Socci ND, Tabar V, Studer L (2008) Human ES cell-derived neural rosettes reveal a functionally distinct early neural stem cell stage. Genes Dev $22: 152-165$

47. Clelland CD, Barker RA, Watts C (2008) Cell therapy in Huntington disease. Neurosurg Focus 24:E9

48. Keene CD, Chang RC, Leverenz JB, Kopyov O, Perlman S, Hevner RF, Born DE, Bird TD, Montine TJ (2009) A patient with Huntington's disease and long-surviving fetal neural transplants that developed mass lesions. Acta Neuropathol 117:329-338

49. Keene CD, Sonnen JA, Swanson PD, Kopyov O, Leverenz JB, Bird TD, Montine TJ (2007) Neural transplantation in Huntington disease: long-term grafts in two patients. Neurology 68:2093-2098

50. Capetian P, Knoth R, Maciaczyk J, Pantazis G, Ditter M, Bokla L, Landwehrmeyer GB, Volk B, Nikkhah G (2009) Histological findings on fetal striatal grafts in a Huntington's disease patient early after transplantation. Neuroscience 160:661-675

51. Amariglio N, Hirshberg A, Scheithauer BW, Cohen Y, Loewenthal R, Trakhtenbrot L, Paz N, Koren-Michowitz M, Waldman D, Leider-Trejo L, Toren A, Constantini S, Rechavi G (2009) Donorderived brain tumor following neural stem cell transplantation in an ataxia telangiectasia patient. PLoS Med 6:e1000029

52. Baker M (2009) Tumours spark stem-cell review. Nature 457:941
53. Jandial R, Snyder EY (2009) A safer stem cell: on guard against cancer. Nat Med 15:999-1001

54. Lavin MF, Gueven N, Bottle S, Gatti RA (2007) Current and potential therapeutic strategies for the treatment of ataxiatelangiectasia. Br Med Bull 81-82:129-147

55. Cao F, Li Z, Lee A, Liu Z, Chen K, Wang H, Cai W, Chen X, Wu JC (2009) Noninvasive de novo imaging of human embryonic stem cell-derived teratoma formation. Cancer Res 69:2709-2713

56. Przyborski SA (2005) Differentiation of human embryonic stem cells after transplantation in immune-deficient mice. Stem Cells 23:1242-1250

57. Wakitani S, Takaoka K, Hattori T, Miyazawa N, Iwanaga $T$, Takeda S, Watanabe TK, Tanigami A (2003) Embryonic stem cells injected into the mouse knee joint form teratomas and subsequently destroy the joint. Rheumatology 42:162-165

58. Magliocca JF, Held IK, Odorico JS (2006) Undifferentiated murine embryonic stem cells cannot induce portal tolerance but may possess immune privilege secondary to reduced major histocompatibility complex antigen expression. Stem Cells Dev 15:707-717

59. Koch CA, Jordan CE, Platt JL (2006) Complement-dependent control of teratoma formation by embryonic stem cells. J Immunol 177:4803-4809

60. Nussbaum J, Minami E, Laflamme MA, Virag JA, Ware CB, Masino A, Muskheli V, Pabon L, Reinecke H, Murry CE (2007) Transplantation of undifferentiated murine embryonic stem cells in the heart: teratoma formation and immune response. FASEB J 21:1345-1357

61. Dressel R, Schindehütte J, Kuhlmann T, Elsner L, Novota P, Baier PC, Schillert A, Bickeböller H, Herrmann T, Trenkwalder C, Paulus W, Mansouri A (2008) The tumorigenicity of mouse embryonic stem cells and in vitro differentiated neuronal cells is controlled by the recipients' immune response. PLoS ONE 3: e2622

62. Martin GR (1981) Isolation of a pluripotent cell line from early mouse embryos cultured in medium conditioned by teratocarcinoma stem cells. Proc Natl Acad Sci USA 78:7634-7638

63. Evans MJ, Kaufman MH (1981) Establishment in culture of pluripotential cells from mouse embryos. Nature 292:154-156

64. Choi D, Oh HJ, Chang UJ, Koo SK, Jiang JX, Hwang SY, Lee JD, Yeoh GC, Shin HS, Lee JS, Oh B (2002) In vivo differentiation of mouse embryonic stem cells into hepatocytes. Cell Transplant 11:359-368

65. Robertson NJ, Brook FA, Gardner RL, Cobbold SP, Waldmann H, Fairchild PJ (2007) Embryonic stem cell-derived tissues are immunogenic but their inherent immune privilege promotes the induction of tolerance. Proc Natl Acad Sci USA 104:20920 20925

66. Cao F, van der Bogt KE, Sadrzadeh A, Xie X, Sheikh AY, Wang H, Connolly AJ, Robbins RC, Wu JC (2007) Spatial and temporal kinetics of teratoma formation from murine embryonic stem cell transplantation. Stem Cells Dev 16:883-891

67. Drukker M, Katchman H, Katz G, Even-Tov Friedman S, Shezen E, Hornstein E, Mandelboim O, Reisner Y, Benvenisty N (2006) Human embryonic stem cells and their differentiated derivatives are less susceptible to immune rejection than adult cells. Stem Cells 24:221-229

68. Thomson JA, Itskovitz-Eldor J, Shapiro SS, Waknitz MA, Swiergiel JJ, Marshall VS, Jones JM (1998) Embryonic stem cell lines derived from human blastocysts. Science 282:1145-1147

69. Prokhorova TA, Harkness LM, Frandsen U, Ditzel N, Schroder HD, Burns JS, Kassem M (2009) Teratoma formation by human embryonic stem cells is site dependent and enhanced by the presence of Matrigel. Stem Cells Dev 18:47-54 
70. Shih CC, Forman SJ, Chu P, Slovak M (2007) Human embryonic stem cells are prone to generate primitive, undifferentiated tumors in engrafted human fetal tissues in severe combined immunodeficient mice. Stem Cells Dev $16: 893-902$

71. Tian X, Woll PS, Morris JK, Linehan JL, Kaufman DS (2006) Hematopoietic engraftment of human embryonic stem cellderived cells is regulated by recipient innate immunity. Stem Cells 24:1370-1380

72. Lee AS, Tang C, Cao F, Xie X, van der Bogt K, Hwang A, Connolly AJ, Robbins RC, Wu JC (2009) Effects of cell number on teratoma formation by human embryonic stem cells. Cell Cycle 8:2608-2612

73. Grinnemo KH, Genead R, Kumagai-Braesch M, Andersson A, Danielsson C, Mansson-Broberg A, Dellgren G, Stromberg AM, Ekberg H, Hovatta O, Sylven C, Corbascio M (2008) Costimulation blockade induces tolerance to HESC transplanted to the testis and induces regulatory T-cells to HESC transplanted into the heart. Stem Cells 26:1850-1857

74. Gutierrez-Aranda I, Ramos-Mejia V, Bueno C, Munoz-Lopez M, Real PJ, Macia A, Sanchez L, Ligero G, Garcia-Parez JL, Menendez P (2010) Human induced pluripotent stem cells develop teratoma more efficiently and faster than human embryonic stem cells regardless the site of injection. Stem Cells 28:1568-1570

75. Dressel R, Nolte J, Elsner L, Novota P, Guan K, StreckfussBomeke K, Hasenfuss G, Jaenisch R, Engel W (2010) Pluripotent stem cells are highly susceptible targets for syngeneic, allogeneic, and xenogeneic natural killer cells. FASEB J 24:2164-2177

76. Drukker M (2006) Immunogenicity of embryonic stem cells and their progeny. Methods Enzymol 420:391-409

77. Swijnenburg RJ, Schrepfer S, Govaert JA, Cao F, Ransohoff K, Sheikh AY, Haddad M, Connolly AJ, Davis MM, Robbins RC, Wu JC (2008) Immunosuppressive therapy mitigates immunological rejection of human embryonic stem cell xenografts. Proc Natl Acad Sci USA 105:12991-12996

78. Cooke MJ, Stojkovic M, Przyborski SA (2006) Growth of teratomas derived from human pluripotent stem cells is influenced by the graft site. Stem Cells Dev 15:254-259

79. Cao F, Drukker M, Lin S, Sheikh AY, Xie X, Li Z, Connolly AJ, Weissman IL, Wu JC (2007) Molecular imaging of embryonic stem cell misbehavior and suicide gene ablation. Cloning Stem Cells 9:107-117

80. Arnhold S, Klein H, Semkova I, Addicks K, Schraermeyer U (2004) Neurally selected embryonic stem cells induce tumor formation after long-term survival following engraftment into the subretinal space. Invest Ophthalmol Vis Sci 45:4251-4255

81. Swijnenburg RJ, Tanaka M, Vogel H, Baker J, Kofidis T, Gunawan F, Lebl DR, Caffarelli AD, de Bruin JL, Fedoseyeva EV, Robbins RC (2005) Embryonic stem cell immunogenicity increases upon differentiation after transplantation into ischemic myocardium. Circulation 112:I166-I172

82. Wobus AM, Holzhausen H, Jakel P, Schoneich J (1984) Characterization of a pluripotent stem cell line derived from a mouse embryo. Exp Cell Res 152:212-219

83. Daley GQ, Scadden DT (2008) Prospects for stem cell-based therapy. Cell 132:544-548

84. Csete M (2010) Translational prospects for human induced pluripotent stem cells. Regen Med 5:509-519

85. Stadtfeld M, Hochedlinger K (2010) Induced pluripotency: history, mechanisms, and applications. Genes Dev 24:22392263

86. Teo AK, Vallier L (2010) Emerging use of stem cells in regenerative medicine. Biochem J 428:11-23
87. Mardanpour P, Guan K, Nolte J, Lee JH, Hasenfuss G, Engel W, Nayernia K (2008) Potency of germ cells and its relevance for regenerative medicine. J Anat 213:26-29

88. Swijnenburg RJ, Schrepfer S, Cao F, Pearl JI, Xie X, Connolly AJ, Robbins RC, Wu JC (2008) In vivo imaging of embryonic stem cells reveals patterns of survival and immune rejection following transplantation. Stem Cells Dev 17:1023-1029

89. Wu DC, Boyd AS, Wood KJ (2008) Embryonic stem cells and their differentiated derivatives have a fragile immune privilege but still represent novel targets of immune attack. Stem Cells 26:1939-1950

90. Kofidis T, deBruin JL, Tanaka M, Zwierzchoniewska M, Weissman I, Fedoseyeva E, Haverich A, Robbins RC (2005) They are not stealthy in the heart: embryonic stem cells trigger cell infiltration, humoral and T-lymphocyte-based host immune response. Eur J Cardiothorac Surg 28:461-466

91. Yachimovich-Cohen N, Even-Ram S, Shufaro Y, Rachmilewitz J, Reubinoff B (2010) Human embryonic stem cells suppress T cell responses via arginase I-dependent mechanism. J Immunol 184:1300-1308

92. Singla DK, Hacker TA, Ma L, Douglas PS, Sullivan R, Lyons GE, Kamp TJ (2006) Transplantation of embryonic stem cells into the infarcted mouse heart: formation of multiple cell types. J Mol Cell Cardiol 40:195-200

93. Koch CA, Geraldes P, Platt JL (2008) Immunosuppression by embryonic stem cells. Stem Cells 26:89-98

94. Bonde S, Zavazava N (2006) Immunogenicity and engraftment of mouse embryonic stem cells in allogeneic recipients. Stem Cells 24:2192-2201

95. Simpson E, Scott D, Chandler P (1997) The male-specific histocompatibility antigen, H-Y: a history of transplantation, immune response genes, sex determination and expression cloning. Annu Rev Immunol 15:39-61

96. Bronte V, Zanovello P (2005) Regulation of immune responses by L-arginine metabolism. Nat Rev Immunol 5:641-654

97. Asano T, Sasaki K, Kitano Y, Terao K, Hanazono Y (2006) In vivo tumor formation from primate embryonic stem cells. Methods Mol Biol 329:459-467

98. Asano T, Ageyama N, Takeuchi K, Momoeda M, Kitano Y, Sasaki K, Ueda Y, Suzuki Y, Kondo Y, Torii R, Hasegawa M, Ookawara S, Harii K, Terao K, Ozawa K, Hanazono Y (2003) Engraftment and tumor formation after allogeneic in utero transplantation of primate embryonic stem cells. Transplantation 76:1061-1067

99. Shibata H, Ageyama N, Tanaka Y, Kishi Y, Sasaki K, Nakamura S, Muramatsu S, Hayashi S, Kitano Y, Terao K, Hanazono Y (2006) Improved safety of hematopoietic transplantation with monkey embryonic stem cells in the allogeneic setting. Stem Cells 24:1450-1457

100. Singla DK, Lyons GE, Kamp TJ (2007) Transplanted embryonic stem cells following mouse myocardial infarction inhibit apoptosis and cardiac remodeling. Am J Physiol Heart Circ Physiol 293:H1308-H1314

101. Min JY, Yang Y, Sullivan MF, Ke Q, Converso KL, Chen Y, Morgan JP, Xiao YF (2003) Long-term improvement of cardiac function in rats after infarction by transplantation of embryonic stem cells. J Thorac Cardiovasc Surg 125:361-369

102. Hodgson DM, Behfar A, Zingman LV, Kane GC, Perez-Terzic C, Alekseev AE, Puceat M, Terzic A (2004) Stable benefit of embryonic stem cell therapy in myocardial infarction. Am J Physiol Heart Circ Physiol 287:H471-H479

103. Min JY, Yang Y, Converso KL, Liu L, Huang Q, Morgan JP, Xiao YF (2002) Transplantation of embryonic stem cells improves cardiac function in postinfarcted rats. J Appl Physiol 92:288-296 
104. Min JY, Huang X, Xiang M, Meissner A, Chen Y, Ke Q, Kaplan E, Rana JS, Oettgen P, Morgan JP (2006) Homing of intravenously infused embryonic stem cell-derived cells to injured hearts after myocardial infarction. J Thorac Cardiovasc Surg 131:889-897

105. Björklund LM, Sanchez-Pernaute R, Chung S, Andersson T, Chen IY, McNaught KS, Brownell AL, Jenkins BG, Wahlestedt C, Kim KS, Isacson O (2002) Embryonic stem cells develop into functional dopaminergic neurons after transplantation in a Parkinson rat model. Proc Natl Acad Sci USA 99:2344-2349

106. Riess P, Molcanyi M, Bentz K, Maegele M, Simanski C, Carlitscheck C, Schneider A, Hescheler J, Bouillon B, Schafer U, Neugebauer E (2007) Embryonic stem cell transplantation after experimental traumatic brain injury dramatically improves neurological outcome, but may cause tumors. J Neurotrauma 24:216-225

107. Molcanyi M, Riess P, Haj-Yasein NN, Bentz K, Loehr M, Kuchta J, Zivcak J, Stenzel W, Miletic H, Hescheler J, Neugebauer E, Hampl JA, Ernestus RI, Schafer U (2009) Developmental potential of the murine embryonic stem cells transplanted into the healthy rat brain-novel insights into tumorigenesis. Cell Physiol Biochem 24:87-94

108. Lin Q, Fu Q, Zhang Y, Wang H, Liu Z, Zhou J, Duan C, Wang Y, Wu K, Wang C (2010) Tumourigenesis in the infarcted rat heart is eliminated through differentiation and enrichment of the transplanted embryonic stem cells. Eur J Heart Fail 12:11791185

109. Caspi O, Huber I, Kehat I, Habib M, Arbel G, Gepstein A, Yankelson L, Aronson D, Beyar R, Gepstein L (2007) Transplantation of human embryonic stem cell-derived cardiomyocytes improves myocardial performance in infarcted rat hearts. J Am Coll Cardiol 50:1884-1893

110. Harkany T, Andang M, Kingma HJ, Gorcs TJ, Holmgren CD, Zilberter Y, Ernfors P (2004) Region-specific generation of functional neurons from naive embryonic stem cells in adult brain. J Neurochem 88:1229-1239

111. Kawai H, Yamashita T, Ohta Y, Deguchi K, Nagotani S, Zhang X, Ikeda Y, Matsuura T, Abe K (2010) Tridermal tumorigenesis of induced pluripotent stem cells transplanted in ischemic brain. $\mathrm{J}$ Cereb Blood Flow Metab 30:1487-1493

112. Fujikawa T, Oh SH, Pi L, Hatch HM, Shupe T, Petersen BE (2005) Teratoma formation leads to failure of treatment for type I diabetes using embryonic stem cell-derived insulin-producing cells. Am J Pathol 166:1781-1791

113. Sipione S, Eshpeter A, Lyon JG, Korbutt GS, Bleackley RC (2004) Insulin expressing cells from differentiated embryonic stem cells are not beta cells. Diabetologia 47:499-508

114. Miura K, Okada Y, Aoi T, Okada A, Takahashi K, Okita K, Nakagawa M, Koyanagi M, Tanabe K, Ohnuki M, Ogawa D, Ikeda E, Okano H, Yamanaka S (2009) Variation in the safety of induced pluripotent stem cell lines. Nat Biotechnol 27:743745

115. Rideout WM 3rd, Hochedlinger K, Kyba M, Daley GQ, Jaenisch R (2002) Correction of a genetic defect by nuclear transplantation and combined cell and gene therapy. Cell 109:17-27

116. Tabayoyong WB, Salas JG, Bonde S, Zavazava N (2009) HOXB4-transduced embryonic stem cell-derived Lin-c-kit + and Lin-Sca-1+ hematopoietic progenitors express $\mathrm{H} 60$ and are targeted by NK cells. J Immunol 183:5449-5457

117. Ma M, Ding S, Lundqvist A, San H, Fang F, Konoplyannikov M, Berry C, Beltran LE, Chen G, Kovacic JC, Boehm M (2010) Major histocompatibility complex-I expression on embryonic stem cell-derived vascular progenitor cells is critical for syngeneic transplant survival. Stem Cells 28:1465-1475

118. Preynat-Seauve O, de Rham C, Tirefort D, Ferrari-Lacraz S, Krause KH, Villard J (2009) Neural progenitors derived from human embryonic stem cells are targeted by allogeneic $\mathrm{T}$ and natural killer cells. J Cell Mol Med 13:3556-3569

119. Lui KO, Boyd AS, Cobbold SP, Waldmann H, Fairchild PJ (2010) A role for regulatory T cells in acceptance of ESC-derived tissues transplanted across an major histocompatibility complex barrier. Stem Cells 28:1905-1914

120. Yang Y, Min JY, Rana JS, Ke Q, Cai J, Chen Y, Morgan JP, Xiao YF (2002) VEGF enhances functional improvement of postinfarcted hearts by transplantation of ESC-differentiated cells. J Appl Physiol 93:1140-1151

121. Malek S, Kaplan E, Wang JF, Ke Q, Rana JS, Chen Y, Rahim BG, Li M, Huang Q, Xiao YF, Verheugt FW, Morgan JP, Min JY (2006) Successful implantation of intravenously administered stem cells correlates with severity of inflammation in murine myocarditis. Pflugers Arch 452:268-275

122. Fair JH, Cairns BA, Lapaglia MA, Caballero M, Pleasant WA, Hatada S, Kim HS, Gui T, Pevny L, Meyer AA, Stafford DW, Smithies O, Frelinger JA (2005) Correction of factor IX deficiency in mice by embryonic stem cells differentiated in vitro. Proc Natl Acad Sci USA 102:2958-2963

123. Kim JH, Auerbach JM, Rodriguez-Gomez JA, Velasco I, Gavin D, Lumelsky N, Lee SH, Nguyen J, Sanchez-Pernaute R, Bankiewicz K, McKay R (2002) Dopamine neurons derived from embryonic stem cells function in an animal model of Parkinson's disease. Nature 418:50-56

124. Brüstle O, Jones KN, Learish RD, Karram K, Choudhary K, Wiestler OD, Duncan ID, McKay RD (1999) Embryonic stem cell-derived glial precursors: a source of myelinating transplants. Science 285:754-756

125. Ben-Hur T, Idelson M, Khaner H, Pera M, Reinhartz E, Itzik A, Reubinoff BE (2004) Transplantation of human embryonic stem cell-derived neural progenitors improves behavioral deficit in Parkinsonian rats. Stem Cells 22:1246-1255

126. Zeng X, Cai J, Chen J, Luo Y, You ZB, Fotter E, Wang Y, Harvey B, Miura T, Backman C, Chen GJ, Rao MS, Freed WJ (2004) Dopaminergic differentiation of human embryonic stem cells. Stem Cells 22:925-940

127. Park CH, Minn YK, Lee JY, Choi DH, Chang MY, Shim JW, Ko JY, Koh HC, Kang MJ, Kang JS, Rhie DJ, Lee YS, Son H, Moon SY, Kim KS, Lee SH (2005) In vitro and in vivo analyses of human embryonic stem cell-derived dopamine neurons. J Neurochem 92:1265-1276

128. Ménard C, Hagege AA, Agbulut O, Barro M, Morichetti MC, Brasselet C, Bel A, Messas E, Bissery A, Bruneval P, Desnos M, Puceat M, Menasche P (2005) Transplantation of cardiaccommitted mouse embryonic stem cells to infarcted sheep myocardium: a preclinical study. Lancet 366:1005-1012

129. Laflamme MA, Gold J, Xu C, Hassanipour M, Rosler E, Police S, Muskheli V, Murry CE (2005) Formation of human myocardium in the rat heart from human embryonic stem cells. Am J Pathol 167:663-671

130. Thinyane K, Baier PC, Schindehütte J, Mansouri A, Paulus W, Trenkwalder C, Flügge G, Fuchs E (2005) Fate of predifferentiated mouse embryonic stem cells transplanted in unilaterally 6-hydroxydopamine lesioned rats: histological characterization of the grafted cells. Brain Res 1045:80-87

131. Bonnevie L, Bel A, Sabbah L, Al Attar N, Pradeau P, Weill B, Le Deist F, Bellamy V, Peyrard S, Menard C, Desnos M, Bruneval P, Binder P, Hagege AA, Puceat M, Menasche P (2007) Is xenotransplantation of embryonic stem cells a realistic option? Transplantation 83:333-335

132. Baier PC, Schindehütte J, Thinyane K, Flügge G, Fuchs E, Mansouri A, Paulus W, Gruss P, Trenkwalder C (2004) Behavioral changes in unilaterally 6-hydroxy-dopamine lesioned rats after transplantation of differentiated mouse embryonic stem cells without morphological integration. Stem Cells 22:396-404 
133. Frenzel LP, Abdullah Z, Kriegeskorte AK, Dieterich R, Lange N, Busch DH, Krönke M, Utermöhlen O, Hescheler J, Saric T (2009) Role of NKG2D-ligands and ICAM-1 in NK cellmediated lysis of murine embryonic stem cells and embryonic stem cell-derived cardiomyocytes. Stem Cells 27:307-316

134. Bradley JA, Bolton EM, Pedersen RA (2002) Stem cell medicine encounters the immune system. Nat Rev Immunol 2:859-871

135. Saric T, Frenzel LP, Hescheler J (2008) Immunological barriers to embryonic stem cell-derived therapies. Cells Tissues Organs 188:78-90

136. Tian L, Catt JW, O'Neill C, King NJ (1997) Expression of immunoglobulin superfamily cell adhesion molecules on murine embryonic stem cells. Biol Reprod 57:561-568

137. Abdullah Z, Saric T, Kashkar H, Baschuk N, Yazdanpanah B, Fleischmann BK, Hescheler J, Krönke M, Utermöhlen O (2007) Serpin-6 expression protects embryonic stem cells from lysis by antigen-specific CTL. J Immunol 178:3390-3399

138. Brower RC, England R, Takeshita T, Kozlowski S, Margulies DH, Berzofsky JA, Delisi C (1994) Minimal requirements for peptide mediated activation of CD8+ CTL. Mol Immunol 31:1285-1293

139. Purbhoo MA, Irvine DJ, Huppa JB, Davis MM (2004) T cell killing does not require the formation of a stable mature immunological synapse. Nat Immunol 5:524-530

140. Sykulev Y, Joo M, Vturina I, Tsomides TJ, Eisen HN (1996) Evidence that a single peptide-MHC complex on a target cell can elicit a cytolytic $\mathrm{T}$ cell response. Immunity 4:565-571

141. Utermöhlen O, Baschuk N, Abdullah Z, Engelmann A, Siebolts U, Wickenhauser C, Stocking C, Krönke M (2009) Immunologic hurdles of therapeutic stem cell transplantation. Biol Chem 390:977-983

142. Medema JP, de Jong J, Peltenburg LT, Verdegaal EM, Gorter A, Bres SA, Franken KL, Hahne M, Albar JP, Melief CJ, Offringa R (2001) Blockade of the granzyme B/perforin pathway through overexpression of the serine protease inhibitor PI-9/SPI-6 constitutes a mechanism for immune escape by tumors. Proc Natl Acad Sci USA 98:11515-11520

143. Fabricius D, Bonde S, Zavazava N (2005) Induction of stable mixed chimerism by embryonic stem cells requires functional Fas/FasL engagement. Transplantation 79:1040-1044

144. Draper JS, Pigott C, Thomson JA, Andrews PW (2002) Surface antigens of human embryonic stem cells: changes upon differentiation in culture. J Anat 200:249-258

145. Li L, Baroja ML, Majumdar A, Chadwick K, Rouleau A, Gallacher L, Ferber I, Lebkowski J, Martin T, Madrenas J, Bhatia M (2004) Human embryonic stem cells possess immuneprivileged properties. Stem Cells 22:448-456

146. Drukker M, Katz G, Urbach A, Schuldiner M, Markel G, Itskovitz-Eldor J, Reubinoff B, Mandelboim O, Benvenisty N
(2002) Characterization of the expression of MHC proteins in human embryonic stem cells. Proc Natl Acad Sci USA 99:98649869

147. Raulet DH (2006) Missing self recognition and self tolerance of natural killer (NK) cells. Semin Immunol 18:145-150

148. Kärre K (2008) Natural killer cell recognition of missing self. Nat Immunol 9:477-480

149. Hayakawa Y, Smyth MJ (2006) NKG2D and cytotoxic effector function in tumor immune surveillance. Semin Immunol 18:176185

150. Groh V, Bahram S, Bauer S, Herman A, Beauchamp M, Spies T (1996) Cell stress-regulated human major histocompatibility complex class I gene expressed in gastrointestinal epithelium. Proc Natl Acad Sci USA 93:12445-12450

151. Groh V, Rhinehart R, Randolph-Habecker J, Topp MS, Riddell SR, Spies T (2001) Costimulation of CD8alphabeta T cells by NKG2D via engagement by MIC induced on virus-infected cells. Nat Immunol 2:255-260

152. Gasser S, Orsulic S, Brown EJ, Raulet DH (2005) The DNA damage pathway regulates innate immune system ligands of the NKG2D receptor. Nature 436:1186-1190

153. Gasser S, Raulet DH (2006) The DNA damage response arouses the immune system. Cancer Res 66:3959-3962

154. Nomura M, Zou Z, Joh T, Takihara Y, Matsuda Y, Shimada K (1996) Genomic structures and characterization of Rae1 family members encoding GPI-anchored cell surface proteins and expressed predominantly in embryonic mouse brain. J Biochem 120:987-995

155. Stern P, Gidlund M, Orn A, Wigzell H (1980) Natural killer cells mediate lysis of embryonal carcinoma cells lacking MHC. Nature 285:341-342

156. Wagner H, Starzinski-Powitz A, Röllinghoff M, Golstein P, Jakob H (1978) T-cell-mediated cytotoxic immune responses to F9 teratocarcinoma cells: cytolytic effector T cells lyse $\mathrm{H}-2-$ negative F9 cells and syngeneic spermatogonia. J Exp Med 147:251-264

157. Elishmereni M, Bachelet I, Levi-Schaffer F (2008) DNAM-1: an amplifier of immune responses as a therapeutic target in various disorders. Curr Opin Investig Drugs 9:491-496

158. Castriconi R, Daga A, Dondero A, Zona G, Poliani PL, Melotti A, Griffero F, Marubbi D, Spaziante R, Bellora F, Moretta L, Moretta A, Corte G, Bottino C (2009) NK cells recognize and kill human glioblastoma cells with stem cell-like properties. J Immunol 182:3530-3539

159. Suarez-Alvarez B, Rodriguez RM, Calvanese V, Blanco-Gelaz MA, Suhr ST, Ortega F, Otero J, Cibelli JB, Moore H, Fraga MF, Lopez-Larrea C (2010) Epigenetic mechanisms regulate MHC and antigen processing molecules in human embryonic and induced pluripotent stem cells. PLoS ONE 5:e10192 